\title{
Effect of Botanical Extracts on Late Blight (Phytopthora infestans) and Productivity of Tomato (Solanum esculentum)
}

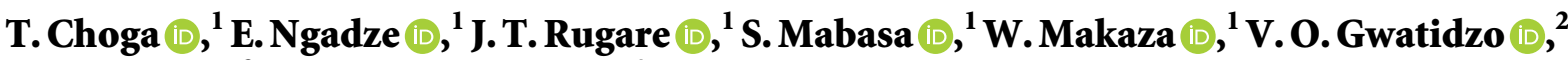 \\ S. Chikuta $\mathbb{D}^{3},{ }^{3}$ and G. Karubanga $\mathbb{D}^{4}$ \\ ${ }^{1}$ University of Zimbabwe, Faculty of Agriculture Environment and Food Systems, \\ Department of Plant Production Sciences and Technologies, Mount Pleasant, Harare, Zimbabwe \\ ${ }^{2}$ Department of Crop Science, Marondera University of Agricultural Sciences and Technology, CSC Campus Industrial Sites, \\ 12 Longlands Road, Marondera, Zimbabwe \\ ${ }^{3}$ Department of Agriculture, Ministry of Agriculture, Chibombo, Zambia \\ ${ }^{4}$ Department of Extension and Innovation Studies, School of Agricultural Sciences, \\ College of Agricultural and Environmental Sciences, Makerere University, Kampala, Uganda
}

Correspondence should be addressed to J. T. Rugare; rugarejoy@yahoo.co.uk

Received 9 July 2020; Revised 21 March 2021; Accepted 24 May 2021; Published 2 June 2021

Academic Editor: Neeti Sanan Mishra

Copyright (c) $2021 \mathrm{~T}$. Choga et al. This is an open access article distributed under the Creative Commons Attribution License, which permits unrestricted use, distribution, and reproduction in any medium, provided the original work is properly cited.

Late blight is caused by Phytopthora infestans (Mont.) de Bary which establishes quickly in Solanum esculentum L. (tomato); as a result, it makes the pathogen one of the most devastating plant diseases across the world. The control of late blight is difficult because $P$. infestans has advanced and complex enzymes and effecter molecules coded by avirulence genes. As such, a study was carried out at the University of Zimbabwe, Department of Plant Production Sciences and Technologies, between August 2018 and May 2019 to evaluate the efficacy of Moringa oleifera Lour. (moringa), Eucalyptus nigra R.T. Baker (gumtree), and Lantana camara L. (sensu lato) (lantana) extracts as biofungicides on late blight development on S. esculentum. The effect of acetone, ethyl acetate, and water extracts of M. oleifera, E. nigra, and L. camara on percent inhibition and radial growth were evaluated in the laboratory. In addition, the efficacy of different extract concentrations of M. oleifera, E. nigra, and L. camara L. on defence enzymes, disease incidence, disease severity, and yield parameters of $S$. esculentum were assessed in the in vivo experiment. Increasing concentration of the botanical extracts significantly $(p \leq 0.05)$ reduced radial growth and increased percent inhibition of $P$. infestans. In addition, increasing botanical extract concentration significantly $(p \leq 0.05)$ increased peroxidase (POD), phenylalanine ammonia lyse (PAL), and polyphenol oxidase (PPO) activity. Disease incidence and severity were significantly $(p \leq 0.05)$ reduced as the concentration of the botanical extracts increased. Similarly, marketable and total yield significantly $(p \leq 0.05)$ increased with increase in the botanical extract concentration. Gas chromatography mass spectrometry (GCMS) revealed the presence of furfural, 5-methyl-4- (trifluoromethyl) pyrido, dodecanamide, cyclopentasiloxane, and decamethyl. From the research, it can be concluded that $M$. oleifera ethyl acetate, E. nigra ethyl acetate, and L. camara water extracts contain antifungal compounds and can be used as biofungicides in late blight management.

\section{Introduction}

Globally, it is reported that late blight caused by Phytopthora infestans L (Mont.) de Bary is one of the most devastating diseases of Solanum esculentum L. (tomato). The pathogen led to the Irish potato famine in the mid-nineteenth century in Ireland which resulted in the death of approximately one million people and emigration of an additional three million from Ireland [1]. The pathogen affects all stages of plant development. $P$. infestans causes disease symptoms such as foliar blight which are characterized by irregular water-soaked spots, and at advanced stages of disease development, green brown lesions are formed [2]. In addition, late blight can also affect large leaves, stems, and dark oblivious spots on tomato fruits [3]. All these symptoms reduce the rate of photosynthesis and concomitantly reduce crop productivity and, on the other hand, increase household food insecurity. To avert the disease, the most widely used control strategy has been 
application of fungicides such as metalaxyl, chlorothalonil, and mancozeb which are usually applied indiscriminately starting from two weeks after transplanting [2].

However, the repeated and injudicious use of these synthetic fungicides was reported to be a key cause of fungicide resistance in P. infestans [4]. For example, reports from Cameroon, Kenya, and Pakistan showed that $P$. infestans has developed resistance to synthetic fungicides with active ingredients such as metalaxyl and chlorothalonil $[2,5,6]$ leading to persistence and surveillance of $S$. esculentum leaf blight. These problems caused by the injudicious use of existing chemical control methods calls for alternative ways of combating the disease. Currently, researchers are advocating for the development of new ways to combat the disease. These strategies include the use of biological control, biopesticides, botanicals, and compost teas which are novel and reportedly effective innovations of intergrated disease management (IDM) [7]. Earlier, scholars reported that these bioagents are environmentally friendly as they are nonpollutive and largely nonphytotoxic [8] and have no residual effects and thus are readily biodegradable, renewable, and inexhaustible [5]. Relatedly, botanical extracts contain antifungal compounds such as phenols, flavonoids, alkaloids, quinones, saponins, tannins, and steroids [2]. However, their fungicidal properties against $P$. infestans have not yet been reported. The antifungal compounds have both direct and indirect effects on P. infestans as they create a conducive environment for the establishment of antagonistic microbes [9].

Elsewhere in the world, botanical extracts in Cameroon [2], Malaysia [10], Slovenia [11], India [3], Kenya [5], and South Africa [12] are now regarded as an important method in IDM practises to control plant diseases in crops. However, their effectiveness in controlling late blight in S. esculentum remains unknown. In this study, the efficacy of $M$. oleifera, E. nigra, and L. camara extracts in controlling $P$. infestans in $S$. esculentum was evaluated. The guiding principle in selection of plants that were used as sources of botanical extracts was their antimicrobial history from published reports by different researchers worldwide $[1,5,8,13]$. It was hypothesised that acetone, ethyl acetate, and water extracts of M. oleifera, E. nigra, and L. camara were effective in suppressing incidence and severity of the pathogen without negatively affecting $S$. esculentum growth and productivity.

\section{Materials and Methods}

2.1. Experimental Site. The experiment was carried in the plant pathology and weed science laboratories at the University of Zimbabwe (UZ). The UZ is situated at a longitude of $31^{\circ} 05^{\prime} \mathrm{N}$ and latitude of $18^{\circ} 12^{\prime} \mathrm{E}$. The temperature ranges between 28 and $36^{\circ} \mathrm{C}$ and $80 \%$ relative humidity. Physical and chemical properties of the soil that was used in the study are given in Table 1.

\subsection{Laboratory Experiment: Evaluatation of the Antifungal Activity of E. nigra, L. camara, and M. oleifera Extracts on Percent Inhibition of $P$. infestans In Vitro}

2.2.1. Experimental Design. The laboratory experiment was laid out as a three-way factorial with botanical extract, extraction solvent, and extract concentration as the factors. The levels for botanical extract were E. nigra, L. camara, and $M$. oleifera extracts, whilst distilled water was used as the control. On the other hand, the levels for extract concentration were $0.5,1.0,2.5$, and $5.0 \mathrm{mg} \mathrm{ml}^{-1}$. Each botanical extract was evaluated in three solvents (acetone, ethyl acetate, and water) to give ten treatments as given in Table 2. Treatments were arranged in a completely randomised design (CRD), and each treatment was replicated four times. The experiment was repeated twice.

\subsubsection{Extraction of Botanical Crude Extracts from Plant} Samples. The crude extracts from plant samples were extracted from six-week-old young leaves using the modified method by Kritzinger [13]. The plant samples were washed under running tap water and rinsed in distilled water. All the plant materials were air dried in the shade for two weeks and ground to powder using a hammer mill grinder (Molinetto Macinatutto, Italy). Sequential extractions were performed on $140 \mathrm{~g}$ of each plant powder by soaking them in $50 \%$ of analytical grade (AR) acetone, $50 \%$ of ethyl acetate (AR), and sterile distilled water (control) for 24 hours, respectively. The crude extracts were filtered using cheese cloth.

Botanical extracts were shaken for 24 hours at room temperature on an orbital shaker (orbital shaker S01, Stuart Scientific Co., Ltd.) at $100 \mathrm{rpm}$. Thereafter, organic solvents in the supernatant were removed at $56^{\circ} \mathrm{C}$ and $77^{\circ} \mathrm{C}$ for acetone and ethyl acetate, respectively, using a rotary evaporator biobase (Model R-200, Switzerland). Thereafter, water plant filtrates were concentrated to powder using a freeze drier (Lastmark laboratory-biobase). The stock solutions of $100 \mathrm{mg}$ of crude extracts per $100 \mathrm{ml}$ of distilled water were prepared, and all the extracts were stored in the refrigerator at $4^{\circ} \mathrm{C}$ until use. Different concentrations $(1.0,2.5$, and $5.0 \mathrm{mg} \mathrm{ml}^{-1}$ ) of each stock solutions were added to $20 \mathrm{ml}$ of potato dextrose agar (PDA) into $90 \mathrm{~mm}$ diameter Petri dishes.

2.2.3. Isolation of P. infestans. Solanum esculentum fruits with blight symptoms were collected from the Agricultural Research Trust (ART) Farm which is situated at a longitude of $16.275^{\circ} \mathrm{S}$, latitude of $31.184^{\circ} \mathrm{E}$, and altitude of $1556 \mathrm{~m}$ above the sea level. The fruits were surface disinfected in $0.15 \mathrm{mg} \mathrm{m}^{-1}$ sodium hypochlorite $(\mathrm{NaHCl})$ for three minutes and rinsed three times in sterile distilled water before being placed on potato dextrose agar (PDA) under continuous ultraviolet light for seven days at $24 \pm 2^{\circ} \mathrm{C}$. The PDA was amended with streptomycin $(2 \mathrm{mg} / 3 \mathrm{ml}$ of distilled water) to inhibit growth of opportunistic pathogens. The $P$. infestans cultures were morphologically identified using a stereomicroscope, subcultured, and stored in a refrigerator at $4^{\circ} \mathrm{C}$ until use.

2.2.4. Inoculation of Pathogen. The PDA containing the different concentrations of botanical extracts was poured into $65 \mathrm{~mm}$ diameter Petri dishes with preset diametrical lines drawn at the bottom plate to identify the centre of the 
TABLe 1: Physical and chemical properties of the soil that was used in the study.

\begin{tabular}{|c|c|c|c|c|c|c|c|c|}
\hline \multirow{2}{*}{ Classification } & \multirow{2}{*}{ Clay (\%) } & \multirow{2}{*}{$\mathrm{pH}\left(\mathrm{CaCl}_{2}\right)$} & \multirow{2}{*}{ Mineral N (mg/kg) } & \multirow{2}{*}{ Available P (mg/kg) } & \multicolumn{4}{|c|}{ Exchangeable cations (\%) } \\
\hline & & & & & $\mathrm{K}$ & $\mathrm{Ca}$ & $\mathrm{Mg}$ & $\mathrm{Na}$ \\
\hline Sandy clay loam & 30 & 5.4 & 8 & 4 & 0.1 & 8.49 & 3.44 & 0.15 \\
\hline
\end{tabular}

TABLE 2: Treatments and location where the botanical extracts were collected.

\begin{tabular}{|c|c|c|c|c|}
\hline \multirow{2}{*}{ Plant type } & \multirow{2}{*}{ Common name } & \multirow{2}{*}{ Solvent used } & \multicolumn{2}{|c|}{ Locations where the botanical extracts were collected } \\
\hline & & & Geographical area & Climate data \\
\hline M. oleifera & Moringa & $\begin{array}{l}\text { Acetone } \\
\text { Ethyl acetate } \\
\text { Water }\end{array}$ & $\begin{array}{l}\text { Africa University, Manicaland, Zimbabwe } \\
\qquad 18^{\circ} 97^{\circ} \mathrm{S}, 32^{\circ} 67^{\circ} \mathrm{E} \\
\text { Altitude: } 1116 \mathrm{~m} \text { above the sea level }\end{array}$ & $\begin{array}{l}\text { Mean temperature }\left(19-25^{\circ} \mathrm{C}\right) \\
\text { Annual rainfall }(1000-1500 \mathrm{~mm})\end{array}$ \\
\hline E. nigra & Gumtree & $\begin{array}{c}\text { Acetone } \\
\text { Ethyl acetate } \\
\text { Water }\end{array}$ & $\begin{array}{c}\text { Crop Science, UZ, Harare } \\
31^{\circ} 05^{\circ} \mathrm{E}, 17^{\circ} 48^{\circ} \mathrm{S} \\
\text { Altitude: } 1523 \mathrm{~m} \text { above the sea level }\end{array}$ & $\begin{array}{l}\text { Mean temperature }\left(15-27^{\circ} \mathrm{C}\right) \\
\text { Annual rainfall }(800-1000 \mathrm{~mm})\end{array}$ \\
\hline L. camara & Lantana & $\begin{array}{l}\text { Acetone } \\
\text { Ethyl acetate } \\
\text { Water }\end{array}$ & $\begin{array}{c}\text { Crop Science, UZ, Harare } \\
31^{\circ} 05^{\circ} \mathrm{E}, 17^{\circ} 48^{\circ} \mathrm{S} \\
\text { Altitude: } 1523 \mathrm{~m} \text { above the sea level }\end{array}$ & $\begin{array}{l}\text { Mean temperature }\left(15-27^{\circ} \mathrm{C}\right) \\
\text { Annual rainfall }(800-1000 \mathrm{~mm})\end{array}$ \\
\hline Distilled water & & Negative control & & \\
\hline
\end{tabular}

plate. Fungal plugs of $5 \mathrm{~mm}$ diameter of P.infestans from seven-day-old fungal cultures were placed using a sterilized cork borer at the centre of the Petri dishes containing PDA amended with the different botanical extracts and sterile distilled water. The inoculated Petri dishes were sealed with Parafilm ${ }^{\circledR}$ and incubated at $25^{\circ} \mathrm{C}$ for 12 days.

\subsubsection{Data Collection}

(1) Radial Growth. The diameter of the radial growth inhibition zones was measured at three, six, and nine days of incubation (DAI) using a Verniar calliper.

(2) Percent Inhibition. Growth inhibition zones were calculated at 3, 6, and 9 DAI using the following formula [12]:

$$
\text { Percentage inhibition }=\frac{(d c-d t)}{d c} * 100 \text {, }
$$

where $d c$ is the average diameter of fungal colony of the negative control; and $d t$ is the average diameter of fungal colonies grown in the presence of the plant extract or the standard fungicides.

(3) Crude Extracts. The quantities (g) of crude extracts harvested from $140 \mathrm{~g}$ plant material using acetone, ethyl acetate, and water solvents were weighed using an analytical scale and are presented in Table 3.

2.2.6. Experimental Design for the Greenhouse Experiment. The glasshouse experiment was laid out as a $4 \times 3 \times 3$ factorial in a completely randomised design with plant type, extraction solvent, and extract concentration as the factors. Each treatment was replicated three times. The levels for plant type were E. nigra, L. camara, and $M$. oleifera, and distilled water as negative control. The levels for extract concentration were 1.0, 2.5, and
TABle 3: Quantities (g) of crude extract harvested from $140 \mathrm{~g}$ plant material using acetone, ethyl acetate, and water.

\begin{tabular}{lcccc}
\hline \multirow{2}{*}{ Common name } & Botanical name & \multicolumn{3}{c}{ Solvents } \\
& & Acetone & Ethyl acetate & Water \\
\hline Moringa & M. oleifera & 20.65 & 10.98 & 26.85 \\
Gumtree & E. nigra & 18.12 & 12.41 & 20.81 \\
Lantana & L. camara & 12.93 & 16.54 & 16.19 \\
\hline
\end{tabular}

$5.0 \mathrm{mg} \mathrm{ml}^{-1}$. Extracts from each plant were extracted using three solvents, namely, acetone, ethyl acetate, and water to give a total of ten treatment combinations as given in Table 2.

2.2.7. Experimental Procedure. Forty-day-old tomato seedlings (cultivar rodade) from Emerald Seedling Company were grown in a green house. Red soil with results given in Table 1 was collected from the Department of Plant Production Sciences and Technologies research fields at UZ and sterilized in an oven at $100^{\circ} \mathrm{C}$ for 24 hours to kill soilborne pathogens. The tomato seedlings were transplanted in perforated black polythene bags with dimensions of $21 \mathrm{~cm}$ height, $15 \mathrm{~cm}$ top diameter, and $11.5 \mathrm{~cm}$ bottom diameter. A total of 168 polythene bags were filled with sterilized red soil up to a height of $15 \mathrm{~cm}$. The sterilized soil was thoroughly mixed with fungal inoculum adjusted to a concentration of $2.5 \times 10^{4}$ spores $\mathrm{ml}^{-1}$ using a haemocytometer (Neubauer improved double, W. Germany). Thereafter, the different botanical extract treatments and the control (Table 2) were sprayed on the $S$. esculentum seedlings at two weeks after transplanting (WAT). Treatments were applied by spraying the extract solution on the tomato foliage to runoff, using a handheld sprayer calibrated to discharge at a spray rate of 100 litres ha $^{-1}$. Pots were watered daily with $500 \mathrm{ml}$ of water using a perforated cup. Basal fertilizer application was done at planting at a rate of $40 \mathrm{~g} \mathrm{pot}^{-1}$ using compound C $(5 \% \mathrm{~N}$ : 
$\left.15 \% \mathrm{P}_{2} \mathrm{O}_{5}: 12 \% \mathrm{~K}_{2} \mathrm{O}\right)$ to achieve an application rate of $800 \mathrm{~kg} \mathrm{ha}^{-1}$. The S. esculentum plants were top-dressed with ammonium nitrate $(34.5 \% \mathrm{~N})$ which was split applied $(5 \mathrm{~g}$ pot $^{-1}$ ) at 3 and 6 WAT to achieve an application rate of $400 \mathrm{~kg} \mathrm{ha}^{-1}$.

2.2.8. Effect of Botanical Extracts on the Activity of Polyphenol Oxidase (PPO), Phenylalanine Ammonia Lyse (PAL). and Peroxidase (POD) on Young S. esculentum Leaves. Defence enzyme activity was measured according to the procedure described by Ngadze et al. [14]. Newly grown leaves of tomatoes were removed from the plant using a scalpel blade every week for six weeks and used in the enzyme assays. The young leaves were ground in liquid nitrogen using a pestle and mortar, and $2.5 \mathrm{~g}$ of homogenate was mixed with $5 \mathrm{ml}$ of $0.05 \mathrm{M}$ sodium phosphate buffer $(\mathrm{pH}$ 6.0 ) containing $5 \%$ polyvinylpolypyrrolidone $\left(\mathrm{wt} \mathrm{vol}^{-1}\right)$. The homogenate was filtered through four layers of muslin cloth, and the filtrate was centrifuged at $13,000 \mathrm{rpm}$ for five minutes at $4^{\circ} \mathrm{C}$. Activity of POD $\left(\mathrm{U} \mu \mathrm{l}^{-1} \mathrm{~min}^{-1}\right)$, PAL

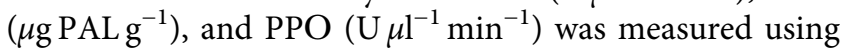
an UV-VIS spectrophotometer (Sahara image).

2.2.9. PPO Assay. One millilitre of supernatant was transferred to a new tube and mixed with $2.9 \mathrm{ml}$ of $0.05 \mathrm{M}$ sodium phosphate buffer and $1 \mathrm{ml}$ of $0.1 \mathrm{M}$ catechol (Sigma). In the control, the extract was replaced with $1 \mathrm{ml}$ of sodium phosphate buffer. Enzyme activity was measured at an absorbance of $540 \mathrm{~nm}$ at 20 -second intervals for four minutes, and values were calculated per minute.

2.2.10. $P O D$ Assay. One millilitre of supernatant was transferred to a new tube and mixed with $2.9 \mathrm{ml}$ of $0.05 \mathrm{M}$ sodium phosphate buffer, $1 \mathrm{ml}$ guaiacol (Sigma), and $1 \mathrm{ml}$ of $2 \% \mathrm{H}_{2} \mathrm{O}_{2}\left(\mathrm{vol} \mathrm{vol}^{-1}\right)$. The resultant mixture was partitioned into three, and absorbance was measured at $540 \mathrm{~nm}$ at 20 second intervals for four minutes.

2.2.11. PAL Assay. One millilitre of supernatant was mixed with $2 \mathrm{ml}$ of $0.05 \mathrm{M}$ borate buffer $(\mathrm{pH} 8.8)$ and $1 \mathrm{ml}$ of $0.02 \mathrm{M}$ $\mathrm{L}$-phenylalanine. The samples were incubated at $30^{\circ} \mathrm{C}$ for one hour. In the control, the extract was replaced with $1 \mathrm{ml}$ of borate buffer $(\mathrm{pH} 8.8)$. The reaction was stopped by adding $0.2 \mathrm{ml}$ of $6 \mathrm{M}$ trichloroacetic acid (TCA). The supernatant was aliquoted into three portions for measurement. One activity unit was defined as a change in absorbance of 0.01 at $540 \mathrm{~nm} \mathrm{~h}^{-1} \mathrm{~g}^{-1}$ protein.

\subsubsection{Data Collection}

(1) Disease Incidence and Severity. Disease incidence was calculated using the following formula:

$$
\text { DI }(\%)=\frac{\text { Number of infected plants }}{\text { Total number of plants in the field }} \times 100 \text {. }
$$

Late blight severity (the proportion of leaf area infected) was estimated visually on each plant with the aid of the modified Horsfall-Barrat rating scale of $1-12 \quad(1=0 \%$, $12=100 \%$ disease severity) (Table 4 ).

(2) Leaves, Stem, and Root Biomass. Individual plants were cut at the base of the stem. Leaves, stem, and roots were dried in an oven at $80^{\circ} \mathrm{C}$ for 72 hours and weighed using a scale (Compact scales and balances, Adam Equipments, USA).

(3) Total and Markertable Yield. Solanum esculentum fruits were harvested, and those without blemishes/deformities were selected and weighed using a scale (Compact scales and balances, Adam Equipments, USA) from each individual plant.

(4) Data Analysis. The data collected were subjected to analysis of variance (ANOVA) using Genstat $18^{\text {th }}$ edition. Mean separation was done using the least significant difference (LSD) at the 5\% significance level. Analysis of late blight disease incidence and severity was done using the Kruskal-Wallis test, and graphs were plotted using Sigma plot version 10 .

(5) Gas Chromatography-Mass Spectrometric (GCMS) Analysis of Antifungal Compounds in Botanical Extracts. Gas chromatography mass spectrometric analysis of E. nigra, L. camara, and M. oleifera samples was done at the Pesticides and Phytochemical Screening Centre at Agilent Technologies, Harare, Zimbabwe. GCMS was used to detect compounds using the relative retention times ranging from 3.14 to 3.40 minutes and elution patterns of components of a mixture in combination with the mass spectral fragmentation patterns, which is the characteristic of a compound's chemical structures [15].

In general, MS are configured with the magnetic sector or quadrupole type mass analyzers. A quadrupole GCMS had a group of four electromagnets that focus each fragment through a slit into the detector. These were programmed to direct only certain fragments, one at a time (scan), until the complete range of $m / z$ was recovered. This produced a mass spectrum, which is a graph of the signal intensity (relative abundance) versus the $\mathrm{m} / z$ ratios (essentially the molecular weight) [15]. Each compound had a unique fingerprint, and software was equipped with a library of spectra for unknown compounds [15]. Antifungal compounds with a score of $80 \%$ and above were considered for data presentation.

\section{Results}

3.1. Laboratory Experiment: Effect of Botanical Extracts on Radial Growth of $P$. infestans. There was a significant $(p \leq 0.005)$ interaction among time $\times$ concentration $\times$ botanical extract on radial growth $(\mathrm{cm})$ of $P$. infestans (Figure 1). E. nigra ethyl acetate, M. oleifera, and L. camara water extracts showed a concentration-dependent reduction of radial growth of $P$. infestans. There was a significant increase of radial growth as time increased from 3 to 12 days after incubation. Maximal reduction of radial growth was 
TABLE 4: Modified Horsfall-Barrat rating scale of late blight disease.

\begin{tabular}{|c|c|c|c|c|c|c|c|c|c|c|c|c|}
\hline Index & 1 & 2 & 3 & 4 & 5 & 6 & 7 & 8 & 9 & 10 & 11 & 12 \\
\hline$\%$ leaf area affected & 0 & $0-3$ & $3-6$ & $6-12$ & $12-25$ & $25-50$ & $50-75$ & $75-87$ & $87-94$ & $94-97$ & $97-100$ & 100 \\
\hline
\end{tabular}
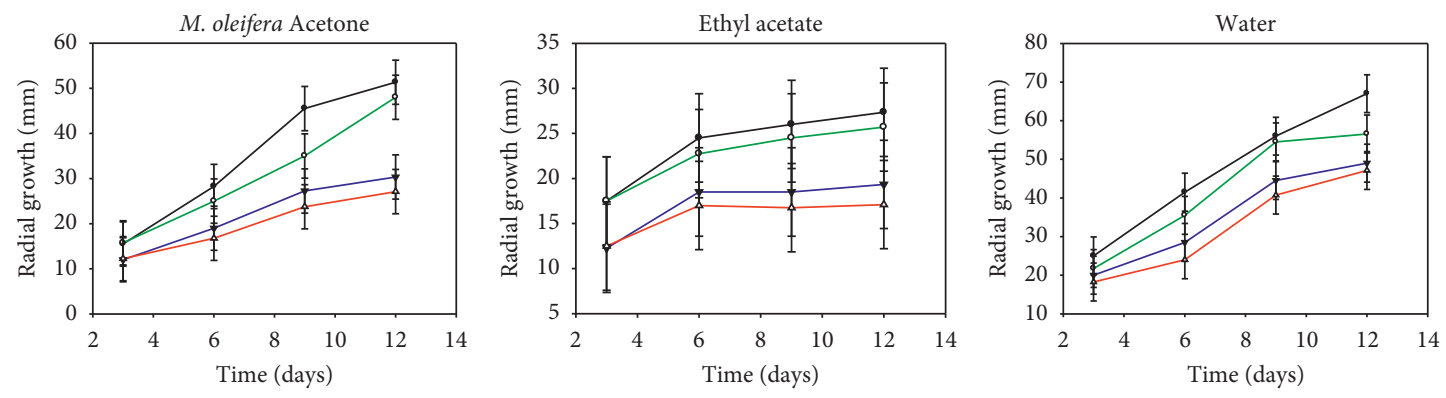

$$
\rightarrow 0.5 \mathrm{mg} \mathrm{ml}^{-1} \rightarrow 2.5
$$$$
\rightarrow 0.5 \mathrm{mg} \mathrm{ml}^{-1} \rightarrow 2.5
$$$$
\rightarrow 0.5 \mathrm{mg} \mathrm{ml}^{-1} \rightarrow 2.5
$$
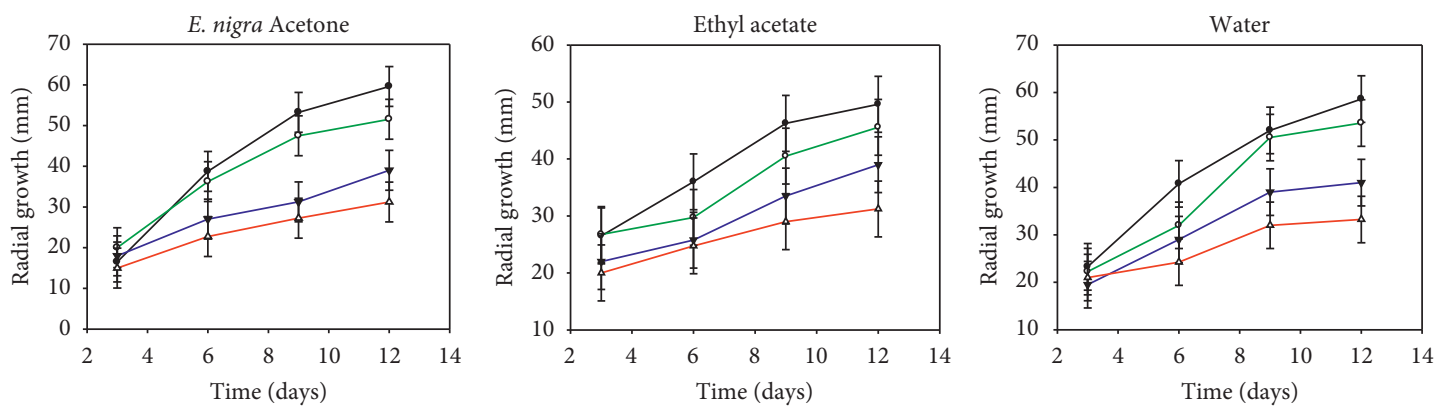

$$
\begin{array}{ll}
\rightarrow & 0.5 \mathrm{mg} \mathrm{ml}^{-1} \rightarrow 2 \\
\rightarrow &
\end{array}
$$

$$
\begin{array}{ll}
\longrightarrow 0 & 0.5 \mathrm{mg} \mathrm{m}^{-1} \rightarrow 2.5 \\
\rightarrow 1 & \longrightarrow 5
\end{array}
$$

$$
\begin{array}{ll}
\longrightarrow & 0.5 \mathrm{mg} \mathrm{ml}^{-1} \rightarrow \\
\longrightarrow & 2.5 \\
&
\end{array}
$$
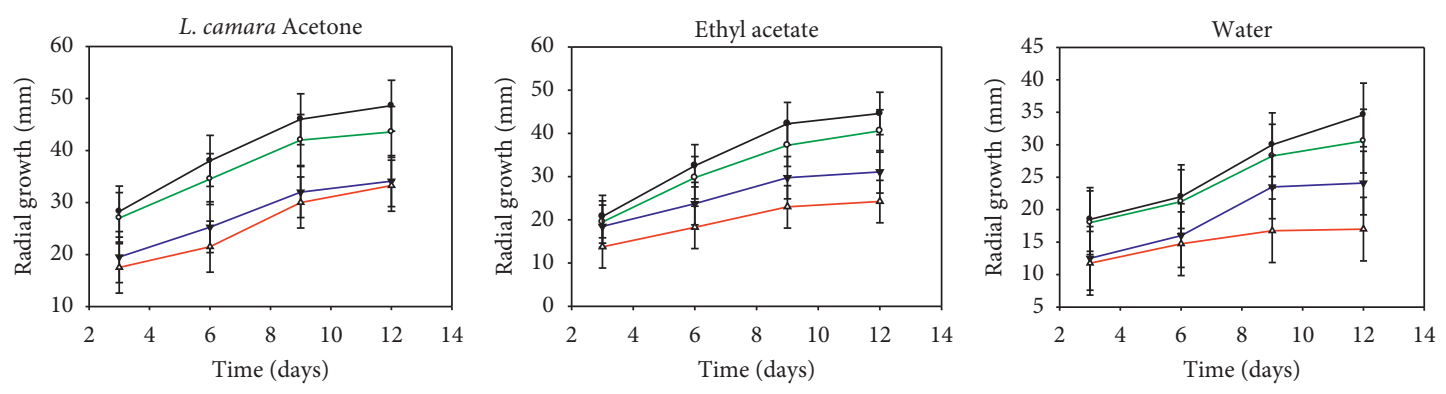

$$
\rightarrow 0.5 \mathrm{mg} \mathrm{ml}^{-1} \rightarrow 2.5
$$

$$
\rightarrow 0.5 \mathrm{mg} \mathrm{ml}^{-1} \rightarrow 2.5
$$$$
\rightarrow 0.5 \mathrm{mg} \mathrm{ml}^{-1} \rightarrow 2.5
$$

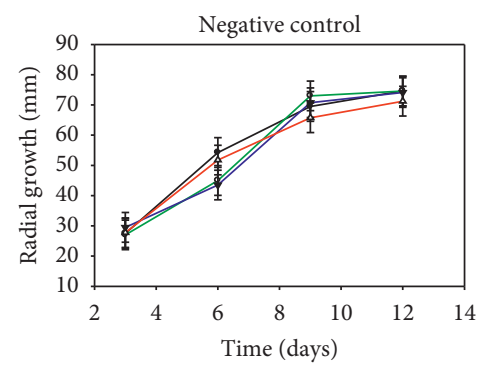

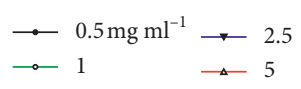

FIGURE 1: Effect of crude botanical extracts on radial growth of $P$. infestans after 3, 6, 9, and 12 days of incubation (DOI). Error bars represent least significant difference (LSD) at $p \leq 0.05$ of a mean pooled from three replications. 
obtained at 2.5 and $5 \mathrm{mg} \mathrm{ml}^{-1}$ botanical extract concentration of $L$. camara water and $M$. oleifera ethyl acetate, respectively. Lantana camara water extract significantly elicited the lowest radial growth as compared to $M$. oleifera water, E. nigra water, and E. nigra acetone extracts. Complete inhibition of $P$. infestans was observed on L. camara water extracts, where $5 \mathrm{mg} \mathrm{ml}^{-1}$ of botanical concentration was used.

\subsection{Effect of Crude Botanical Extracts on Percent Inhibition of} $P$. infestans. The interaction between botanical extrac$\mathrm{t} \times$ extraction solvent $\times$ extract concentration on the percent (\%) inhibition of $P$. infestans was significant $(p \leq 0.05)$. Figure 2 shows that percent inhibition was significantly lower in E. nigra water extracts at 12 days of incubation compared to the other botanical extracts. The percent inhibition was significantly reduced as the days of incubation (DOI) increased. On the other hand, the extract concentration of $5 \mathrm{mg} \mathrm{ml}^{-1}$ significantly increased the percent inhibition of $P$. infestans.

\subsection{Greenhouse Experiment}

3.3.1. Effect of Botanical Extracts on POD. Results of the effects of botanical extracts on POD showed a significant $(p \leq 0.05)$ three-way interaction among botanical extract $\times$ concentration $\times$ time on the activity of POD (U $\mu \mathrm{l}^{-1} \mathrm{~min}^{-1}$ ) in tomato plants infested with late blight (Figure 3). POD activity significantly increased as the time progressed from 1 to 6 WAT. There was a significant increase in POD activity as the concentration of botanical extracts increased from 1.0 to $5.0 \mathrm{mg} \mathrm{ml}^{-1}$ in $M$. oleifera ethyl acetate, E. nigra ethyl acetate, and all $L$. camara extracts. However, E. nigra and M. oleifera water extracts showed a concentration-dependent reduction in the activity of POD.

3.3.2. Effect of Botanical Extracts on PPO. Results of the effects of botanical extracts on PPO activity in S. esculentum plants after innoculation are given in Figure 4 . The results show a significant $(p \leq 0.05)$ botanical extracts $\times$ concentration $\times$ time interaction on the activity of PPO (U $\mu \mathrm{l}^{-1} \mathrm{~min}^{-1}$ ) in S. esculentum plants infected with $P$. infestans (Figure 4). M. oleifera ethyl acetate, E. nigra ethyl acetate, and $L$. camara extracts extracts at $1 \mathrm{mg} \mathrm{ml}^{-1}$ significantly reduced the activity of PPO. For most (except $M$. oleifera and E. nigra water) extracts, there was a concentration-dependent increase in PPO activity. Conversely, PPO activity decreased in the negative control (distilled water).

3.3.3. Effect of Botanical Extracts on PAL. Results of the effects of botanical extracts on PAL activity on S. esculentum plants after inoculation are given in Figure 5. The interaction among botanical extract $\times$ concentration $\times$ time was significant $(p \leq 0.05)$ on PAL activity $\left(\mu \mathrm{g} \mathrm{PAL} \mathrm{g}^{-1}\right)$. Results show that increasing the extract concentration from 1 to $5 \mathrm{mg} \mathrm{ml}^{-1}$ significantly increased PAL activity in plants treated with
M. oleifera ethyl acetate, E. nigra ethyl acetate, and L. camara extracts extracts.

3.3.4. Effect of Botanical Extracts on the Leaves, Stem, and Root Biomass. There was a significant $(p \leq 0.05)$ concentration $\times$ botanical extract interaction on the leaves, stem, and root biomass of $S$. esculentum plants infested with $P$. infestans (Figure 6). Extracts from $M$. oleifera ethyl acetate, E. nigra ethyl acetate, and L. camara water extracts showed a concentration-dependent increase of the leaves, stem, and root biomass. Highest biomass on the leaves, stems, and roots was obtained where plants were treated with 2.5 and $5 \mathrm{mg} \mathrm{ml}^{-1}$ botanical extract concentrations of $M$. oleifera ethyl acetate and L. camara water extract. The leaves, stem, and root biomass was significantly higher on $M$. oleifera ethyl acetate, E. nigra ethyl acetate, and L. camara extracts. However, L camara water, E. nigra water, L camara acetone extracts, and the negative control significantly reduced the leaves, stem, and root biomass (Figure 6).

3.3.5. Effect of Botanical Extracts on the Yield total and Yield Parameters. There was a significant $(p \leq 0.05)$ concentration $\times$ botanical extract interaction on the total and marketable yield of $S$. esculentum plants infested with $P$. infestans (Figure 7). Extracts from $M$. oleifera ethyl acetate, E. nigra ethyl acetate, and L. camara showed a concentration-dependent increase on the yield of S. esculentum. Highest total and marketable yield were obtained at 2.5 and $5 \mathrm{mg} \mathrm{ml}^{-1}$ botanical extract concentration in plants treated with E. nigra ethyl acetate, E. nigra ethyl acetate, and L. camara water extract (Figures 7 and 8). There were no marketable $S$. esculentum fruits obtained from plants that were treated with distilled water (negative control).

3.3.6. Disease Incidence. The interaction of botanical extract $\times$ concentration $\times$ time on $P$. infestans incidence on S. esculentum was significant $(p \leq 0.05)$. Figure 9 shows that $M$. oleifera ethyl acetate, E. nigra ethyl acetate, L. camara water, and L. camara acetone extracts significantly reduced disease incidence of late blight. However, disease incidence was significantly higher on tomato plants treated with $M$. oleifera water and E. nigra water extracts compared to the other treatments. As the number of weeks increased from 5 to 11 WAT, E. nigra ethyl acetate, $M$. oleifera ethyl acetate, and $L$. camara water extracts significantly reduced disease incidence of late blight. In addition, increasing extract concentration from 1 to $2.5 \mathrm{mg} \mathrm{ml}^{-1}$ significantly reduced disease incidence. However, extract concentration of $2.5 \mathrm{mg} \mathrm{ml}^{-1}$ was not significantly different to $5.0 \mathrm{mg} \mathrm{ml}^{-1}$ on $S$. esculentum plants treated with $M$. oleifera ethyl acetate and L. camara water extracts.

3.3.7. Disease Severity. There was a significant $(p \leq 0.05)$ time $\times$ concentration $\times$ botanical extract interaction on the disease severity of $P$. infestans (Figure 10). L. camara acetone, E. nigra ethyl acetate, $M$. oleifera ethyl acetate, and L. camara water extracts caused a concentration-dependent reduction 

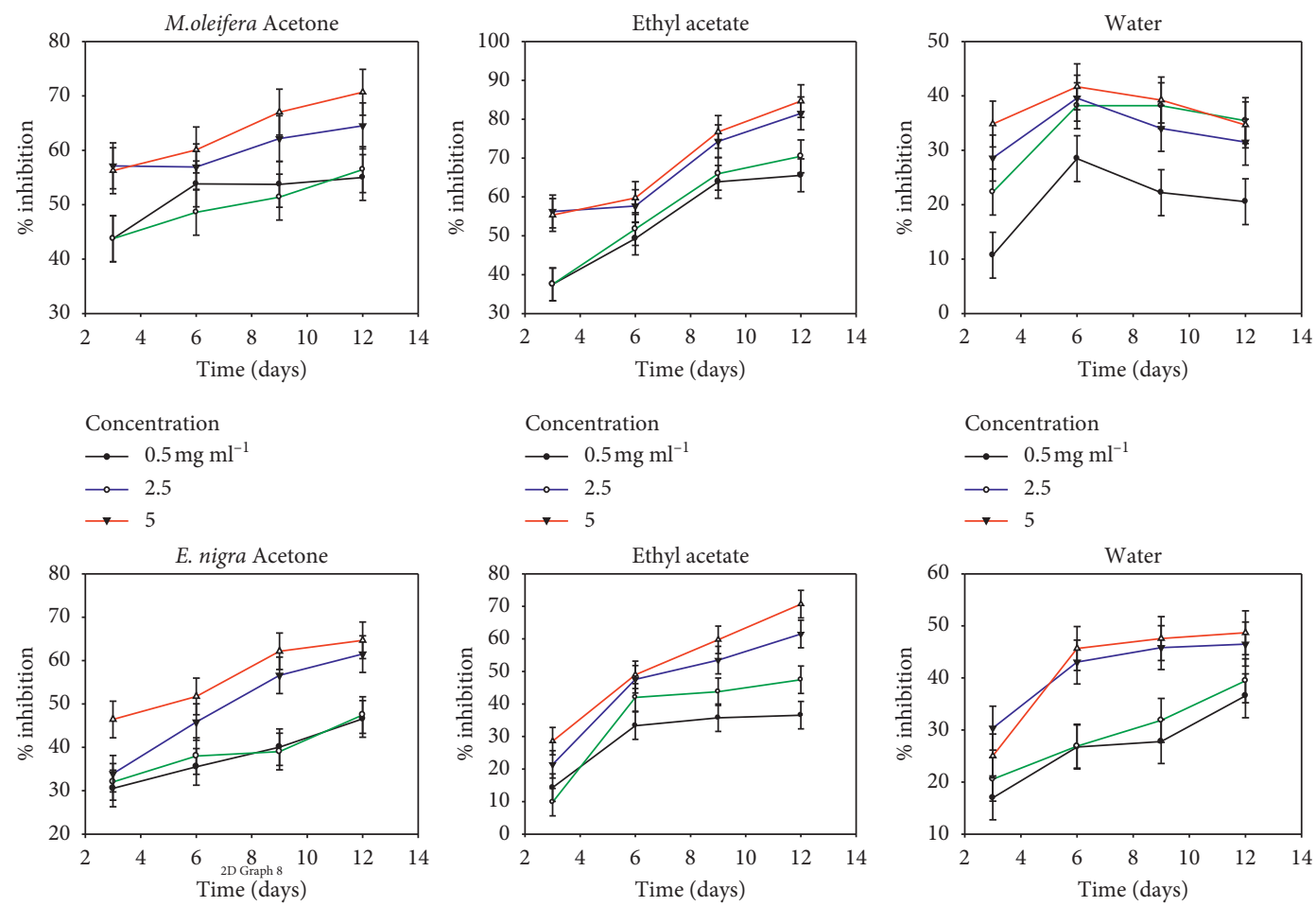

$$
\begin{aligned}
& \text { Concentration } \\
& \longrightarrow 0.5 \mathrm{mg} \mathrm{ml}^{-1} \\
& \longrightarrow \quad 2.5 \\
& \longrightarrow 5
\end{aligned}
$$
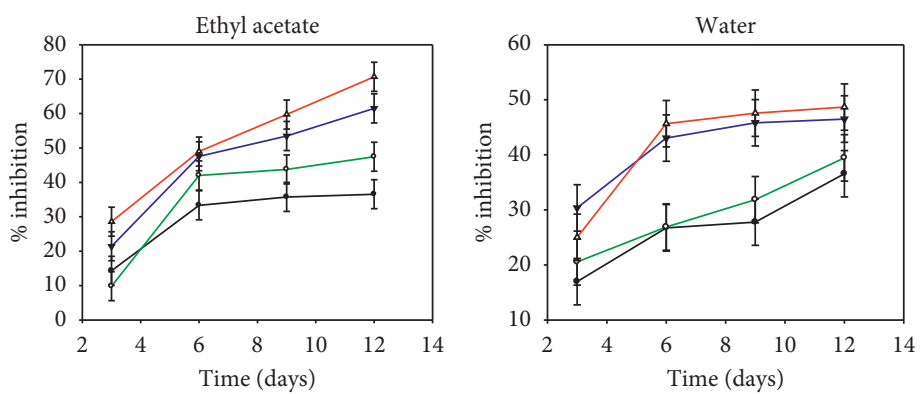

Concentration

$\longrightarrow 0.5 \mathrm{mg} \mathrm{ml}^{-1}$

$\multimap 2.5$

$\rightarrow 5$

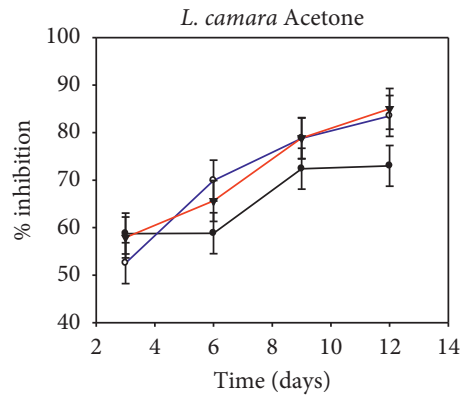

Concentration

$\longrightarrow 0.5 \mathrm{mg} \mathrm{ml}^{-1}$

$\multimap 2.5$

$\rightarrow 5$

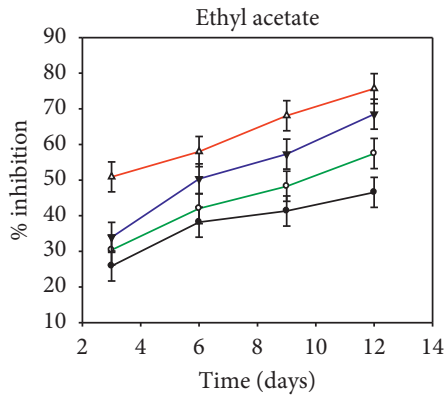

Concentration

$\multimap 0.5 \mathrm{mg} \mathrm{ml}^{-1}$

$\longrightarrow 2.5$

$\rightarrow 5$

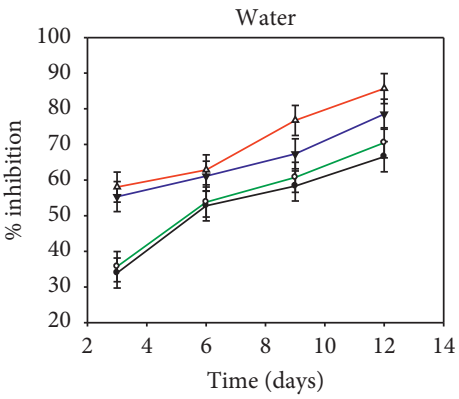

Concentration
$\longrightarrow 0.5 \mathrm{mg} \mathrm{ml}^{-1}$
$\multimap-2.5$
$\longrightarrow 5$

Concentration

$\longrightarrow 0.5 \mathrm{mg} \mathrm{ml}^{-1}$

$\multimap 2.5$

$\rightarrow 5$

Figure 2: Effect of crude botanical extracts on $\%$ inhibition of $P$. infestans in vitro. Error bars represent LSD at $p \leq 0.05$ of a mean pooled from three replications.

on disease severity (Figure 10). Disease severity was significantly reduced at 2.5 and $5 \mathrm{mg} \mathrm{ml}^{-1}$ botanical extract concentration on plants treated with $M$. oleifera ethyl acetate and $L$. camara water extracts. Disease severity was significantly reduced on M. oleifera ethyl acetate, E. nigra ethyl acetate, and L. camara water extracts. However, M. oleifera water, E. nigra water, L. camara acetone extracts, and the negative control significantly increased disease severity.

3.3.8. Gas Chromatography-Mass Spectrometric Analysis of Botaniucal Extracts of M. oleifera, A. Indica, E. nigra, and $L$. camara. GC-MS analysis of $M$. oleifera acetone,
$M$. oleifera ethyl acetate, and $M$. oleifera water extracts showed major molecular peaks at different $m / z$ values of the possible antifungal compounds as given in Table 5 . Tentative identification of compounds shows that the major compounds in M. oleifera acetone, M. oleifera ethyl acetate, and $M$. oleifera water extracts were cyclopentasiloxane, decamethyl, 3,4-dihydroxyphenylglycol, 4TMS derivative, and acenaphthene, respectively (Table 5). Different compounds were extracted by different compounds except cyclopentasiloxane, decamethyl- which was detected in both acetone and water extracts.

The GCMS results for different E. nigra extracts are given in Table 6. Ethyl acetate extracted furfural and eucalyptol both 

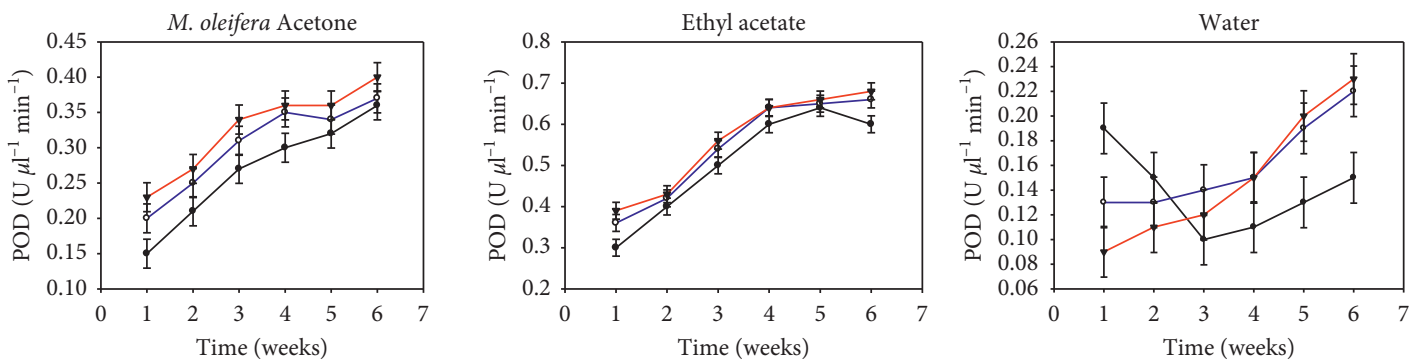

$$
\begin{aligned}
& \text { Concentration } \\
& \longrightarrow \quad 0.5 \mathrm{mg} \mathrm{ml}^{-1} \\
& \longrightarrow-2.5 \\
& \longrightarrow 5
\end{aligned}
$$

Concentration

$\multimap 0.5 \mathrm{mg} \mathrm{ml}^{-1}$

$\multimap 2.5$

$\rightarrow 5$
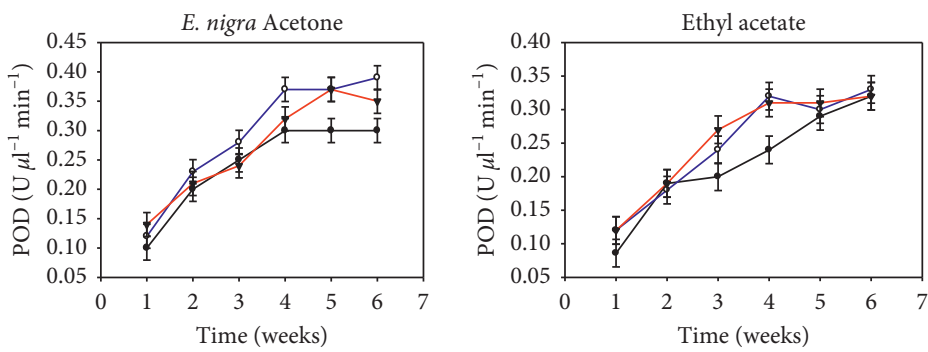

Concentration

$\longrightarrow 0.5 \mathrm{mg} \mathrm{ml}^{-1}$

$\because 2.5$

$\rightarrow 5$

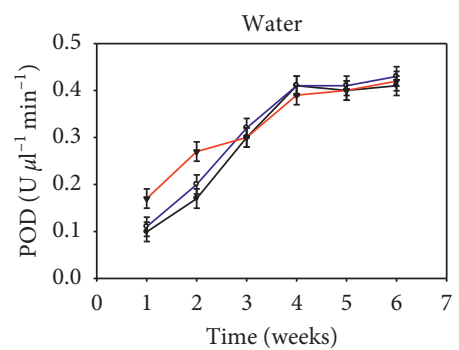

Concentration

$\multimap 0.5 \mathrm{mg} \mathrm{ml}^{-1}$

$\longrightarrow 2.5$

Concentration

$\because 0.5 \mathrm{mg} \mathrm{ml}^{-1}$

$\multimap 2.5$

$\longrightarrow 5$

Concentration

$\longrightarrow 0.5 \mathrm{mg} \mathrm{ml}^{-1}$

$\multimap 2.5$

$\rightarrow 5$
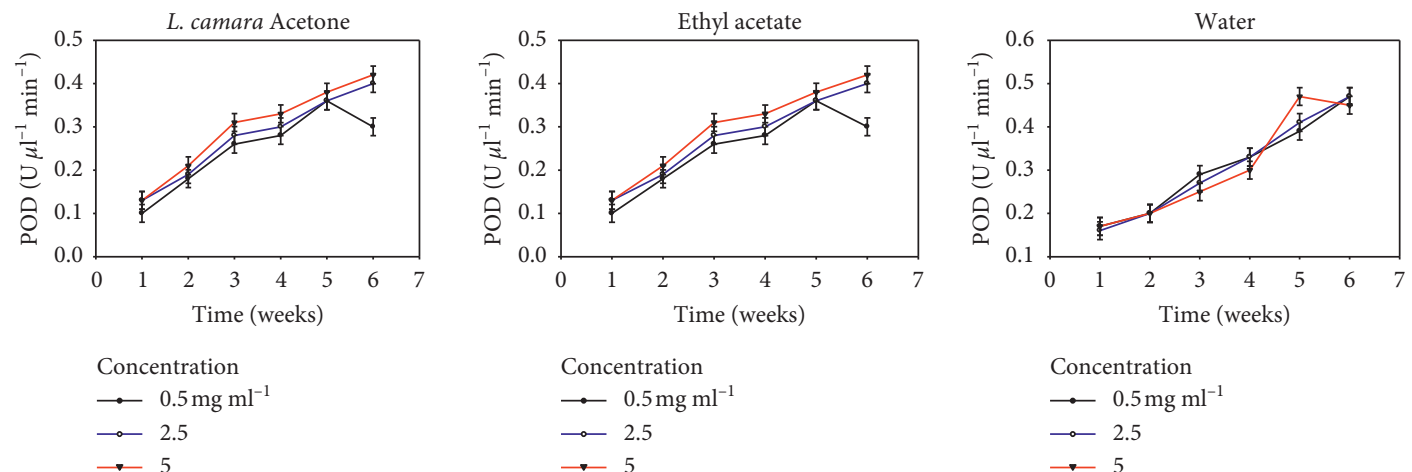

Concentration

$\longrightarrow 0.5 \mathrm{mg} \mathrm{ml}^{-1}$

Concentration

$\multimap 2.5$

$\longrightarrow 0.5 \mathrm{mg} \mathrm{ml}^{-1}$

$\multimap 2.5$

$\longrightarrow 5$

- 5

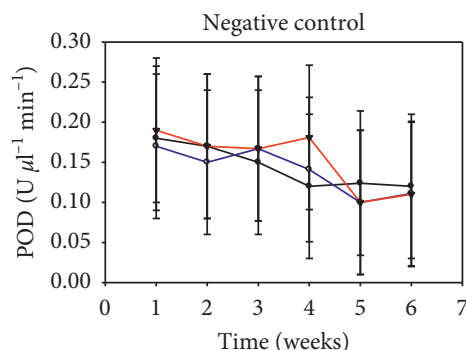

Concentration

$\longrightarrow 0.5 \mathrm{mg} \mathrm{ml}^{-1}$

$\multimap 2.5$

$\rightarrow 5$

FIgURE 3: Effect of botanical exrtracts on POD activity in S. esculentum plants after innoculation with $P$. infestans under glasshouse conditions at the University of Zimbabwe. Error bars represent LSD at $p \leq 0.05$ of a mean pooled from three replications. 

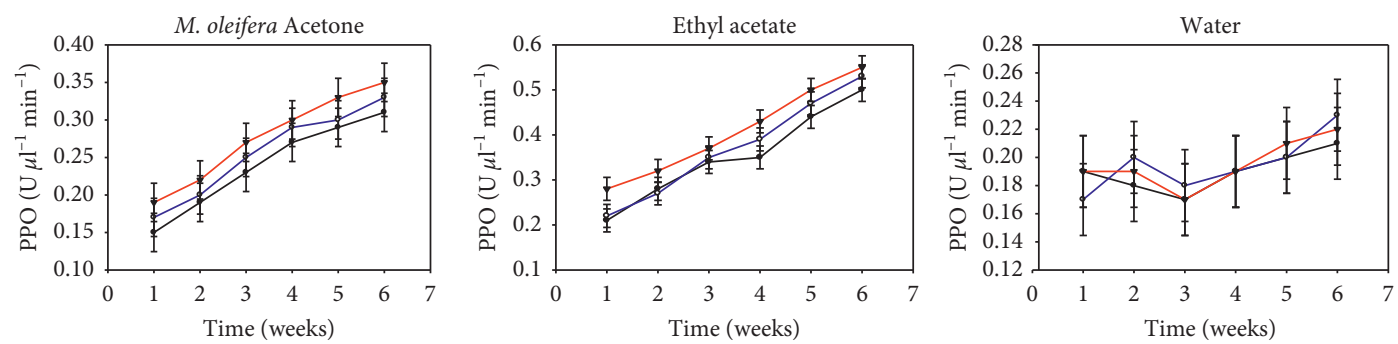

$$
\begin{aligned}
& \text { Concentration } \\
& \longrightarrow \quad 0.5 \mathrm{mg} \mathrm{ml}^{-1} \\
& \longrightarrow \quad 2.5 \\
& \longrightarrow \quad 5
\end{aligned}
$$

Concentration

$\multimap 0.5 \mathrm{mg} \mathrm{ml}^{-1}$

$\multimap 2.5$

$\rightarrow 5$
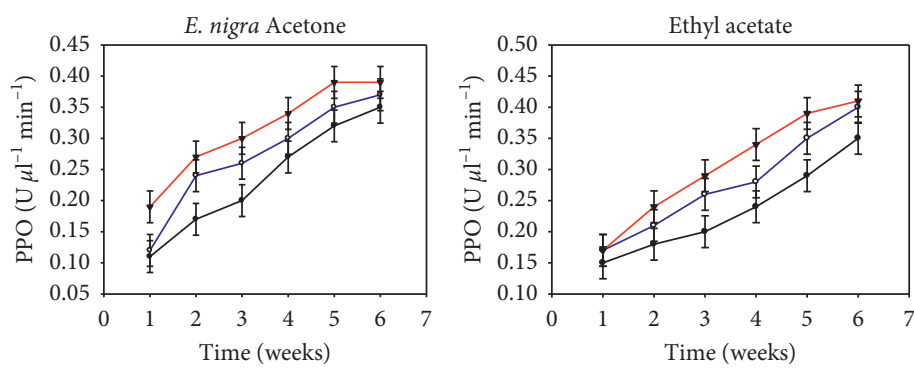

$$
\begin{aligned}
& \text { Concentration } \\
& \longrightarrow \quad 0.5 \mathrm{mg} \mathrm{ml}^{-1} \\
& \square \quad 2.5 \\
& \longrightarrow \quad 5
\end{aligned}
$$

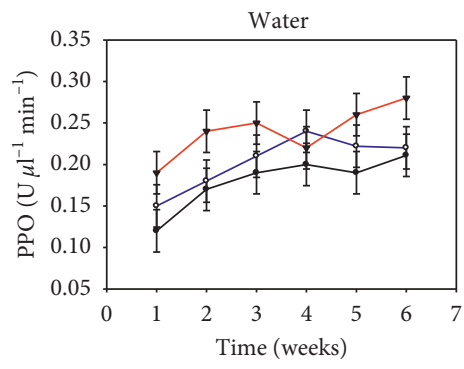

Concentration

Concentration

$\longrightarrow 0.5 \mathrm{mg} \mathrm{ml}^{-1}$

$\longrightarrow 2.5$

$\multimap 2.5$

$\longrightarrow 5$
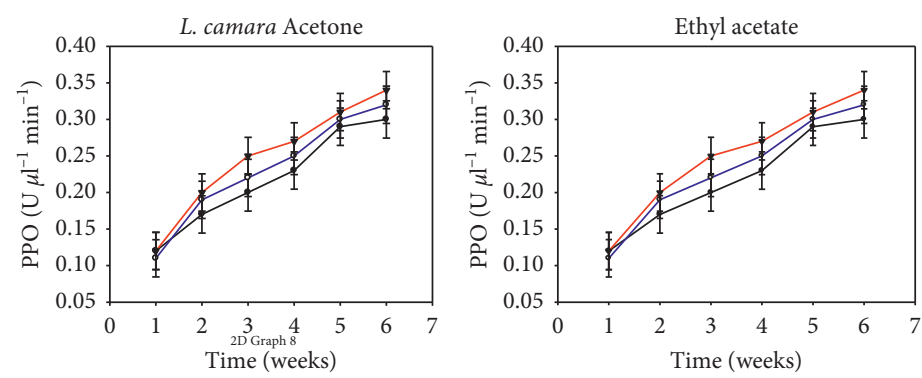

Concentration

$\longrightarrow 0.5 \mathrm{mg} \mathrm{ml}^{-1}$

$\multimap 2.5$

$\longrightarrow 5$
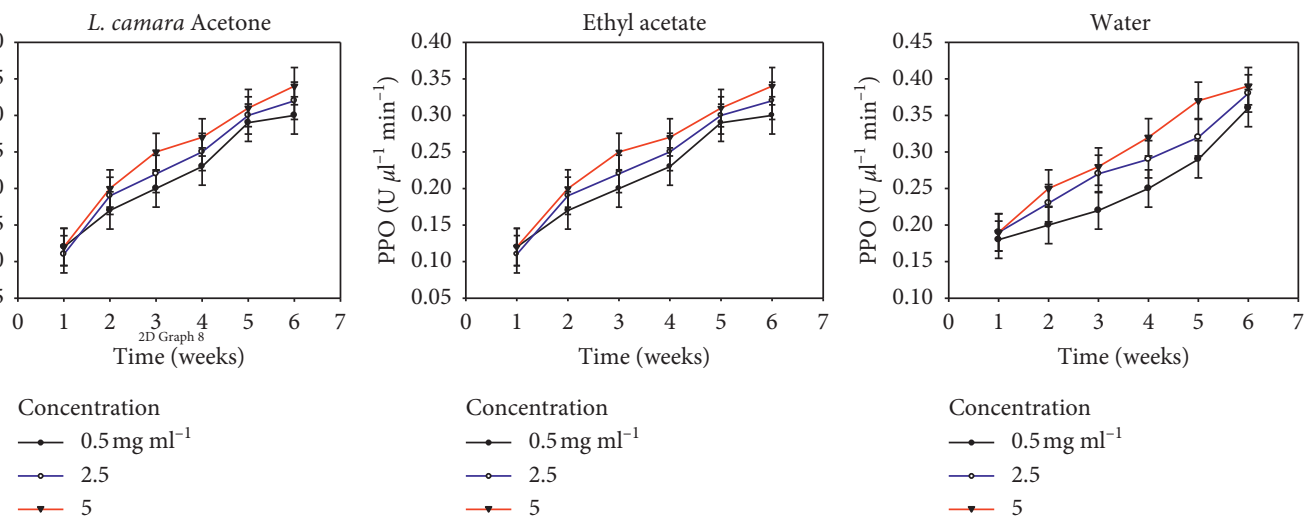

Concentration

$\longrightarrow 0.5 \mathrm{mg} \mathrm{ml}^{-1}$

$\multimap 2.5$

Concentration

$\longrightarrow 0.5 \mathrm{mg} \mathrm{ml}^{-1}$

$\multimap 2.5$

$\rightarrow 5$

$\longrightarrow 5$

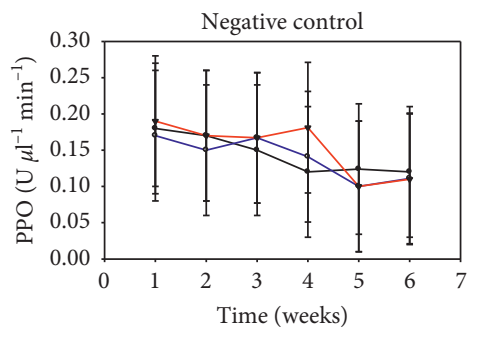

$$
\begin{aligned}
& \text { Concentration } \\
& \longrightarrow 0.5 \mathrm{mg} \mathrm{ml}^{-1} \\
& \longrightarrow \quad 2.5 \\
& \longrightarrow 5
\end{aligned}
$$

FIGURE 4: Effect of different botanical exrtracts on PPO activity of S. esculentum plants after innoculation with $P$. infestans under glasshouse conditions at the University of Zimbabwe. Error bars represent LSD at $p \leq 0.05$ of a mean pooled from three replications. 

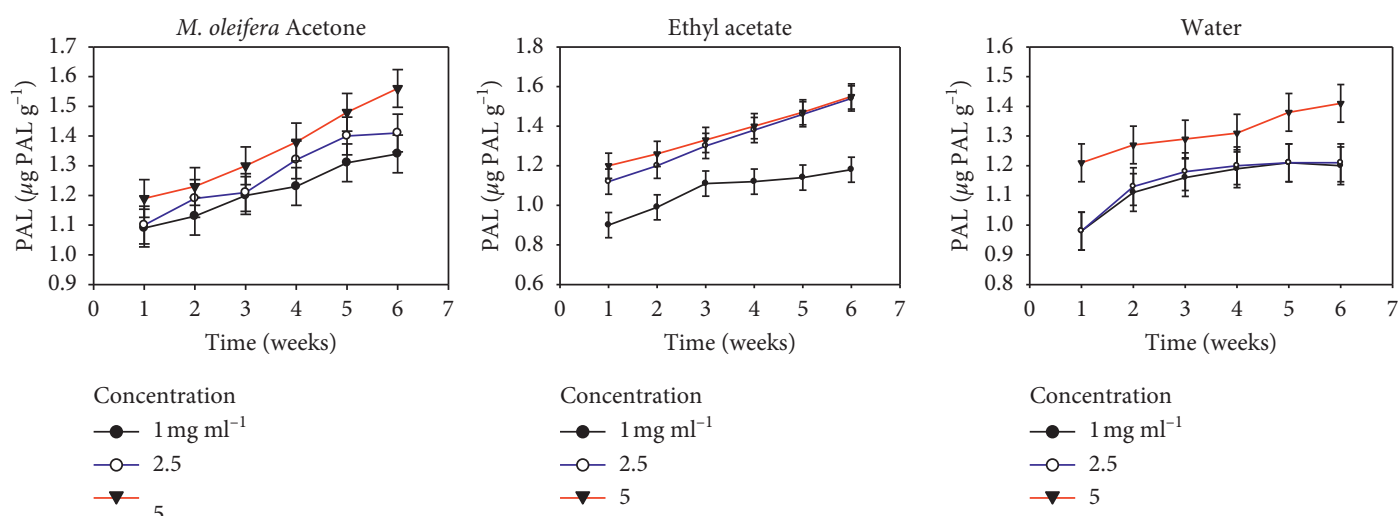

$$
\begin{aligned}
& \text { Concentration } \\
& \longrightarrow-1 \mathrm{mg} \mathrm{ml}^{-1} \\
& \multimap-2.5 \\
& \longrightarrow-5
\end{aligned}
$$
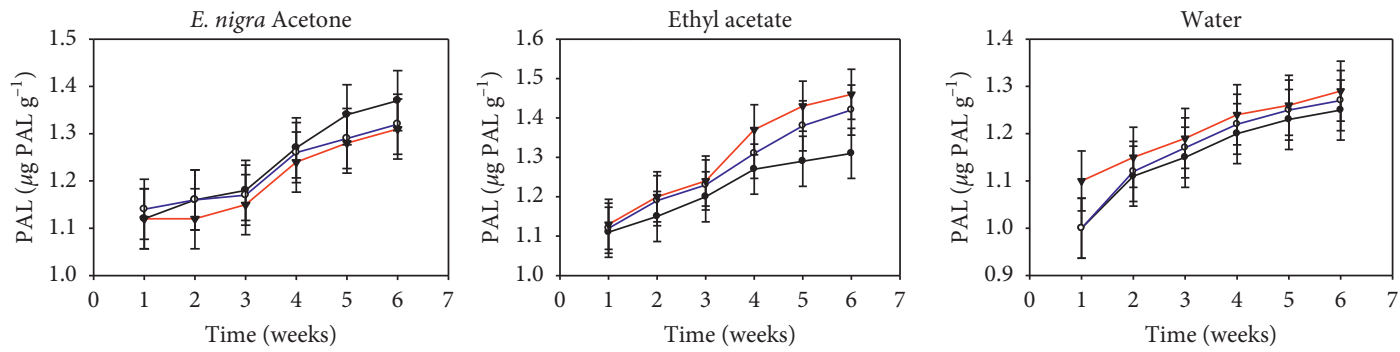

Concentration

Concentration

$\multimap 1 \mathrm{mg} \mathrm{ml}^{-1}$

$-2.5$

$-0-2.5$

$\rightarrow-5$

$\rightarrow 5$
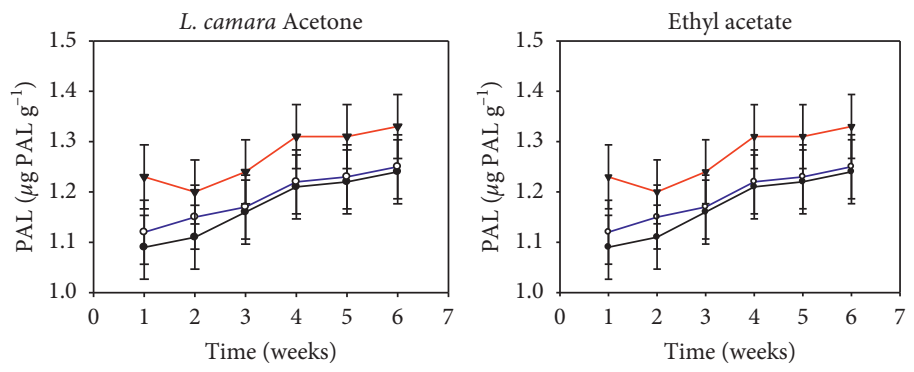

Concentration

$\longrightarrow 1 \mathrm{mg} \mathrm{ml}^{-1}$

$-\infty 2.5$

$\rightarrow 5$
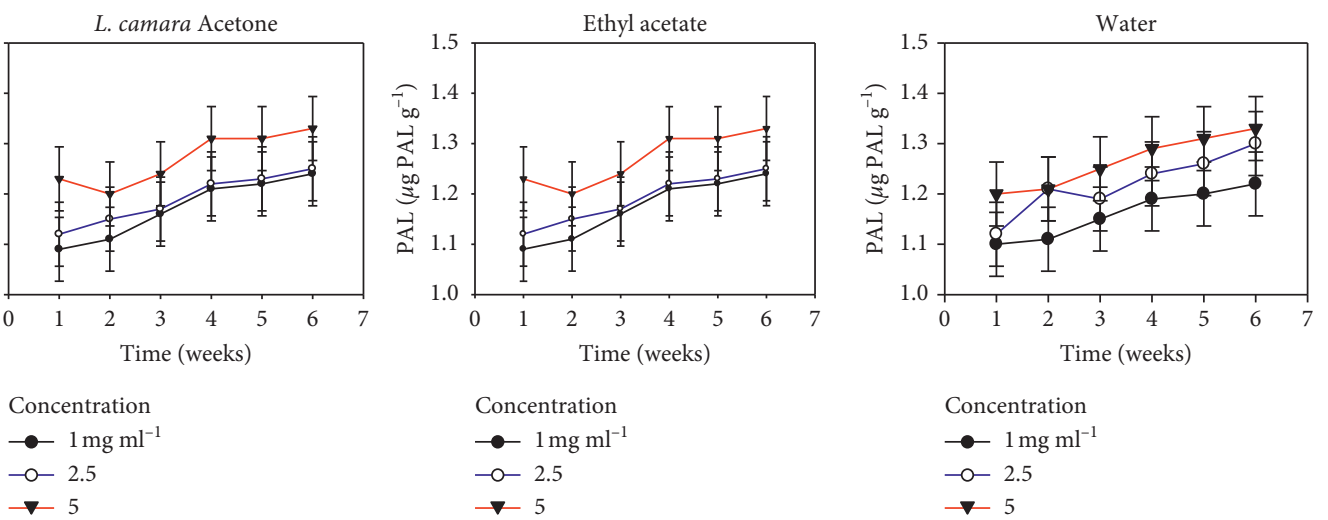

Concentration

$\rightarrow 1 \mathrm{mg} \mathrm{ml}^{-1}$

$-0-2.5$

Concentration

$\longrightarrow 1 \mathrm{mg} \mathrm{ml}^{-1}$

$\rightarrow-2.5$

$\rightarrow 5$

$\rightarrow-5$

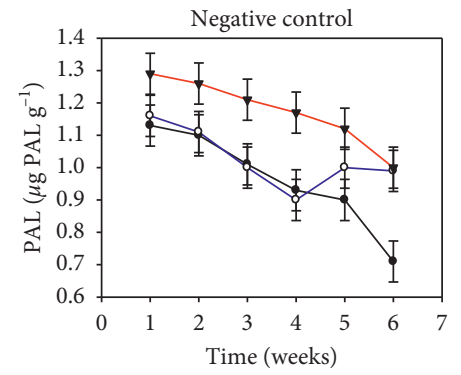

$$
\begin{aligned}
& \text { Concentration } \\
& \longrightarrow-1 \mathrm{mg} \mathrm{ml}^{-1} \\
& -\infty \quad 2.5 \\
& \longrightarrow-5
\end{aligned}
$$

Figure 5: Effect of botanical extracts on the PAL of S. esculentum plants after innoculation with P. infestans under glasshouse conditions at the University of Zimbabwe. Error bars represent LSD at $p \leq 0.05$ of a mean pooled from three replications. 

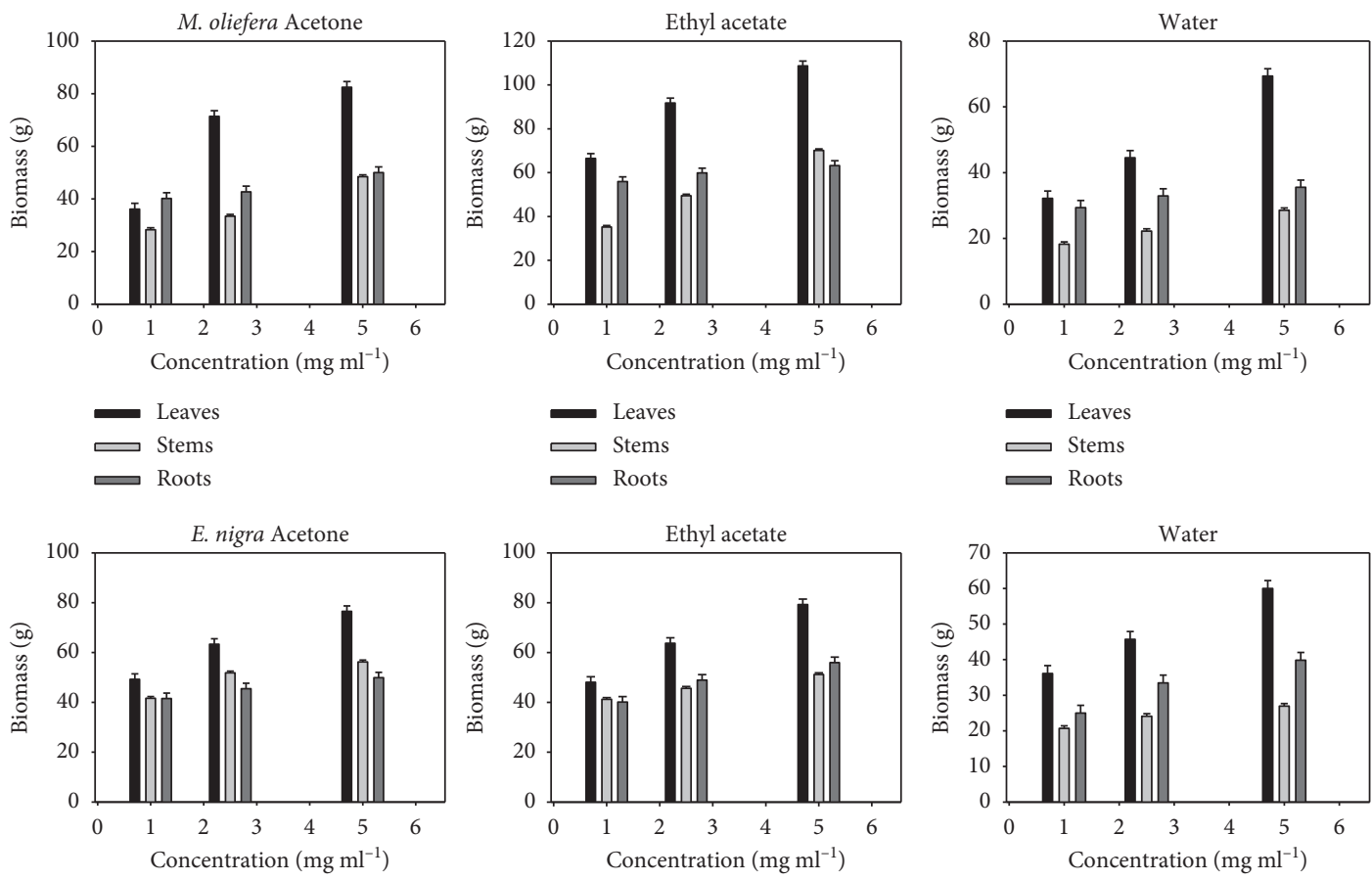

$$
\begin{aligned}
& \text { Leaves } \\
& \text { Stems } \\
& \text { Roots }
\end{aligned}
$$

$$
\text { Leaves }
$$
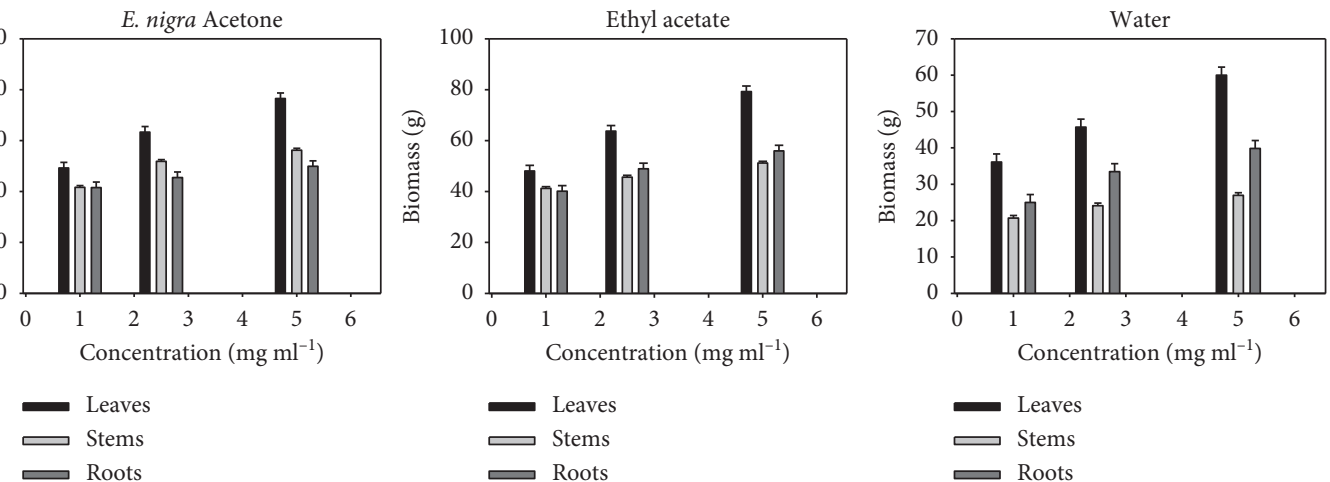

$$
\text { Leaves }
$$$$
\text { Leaves }
$$$$
\text { Stems }
$$

Roots
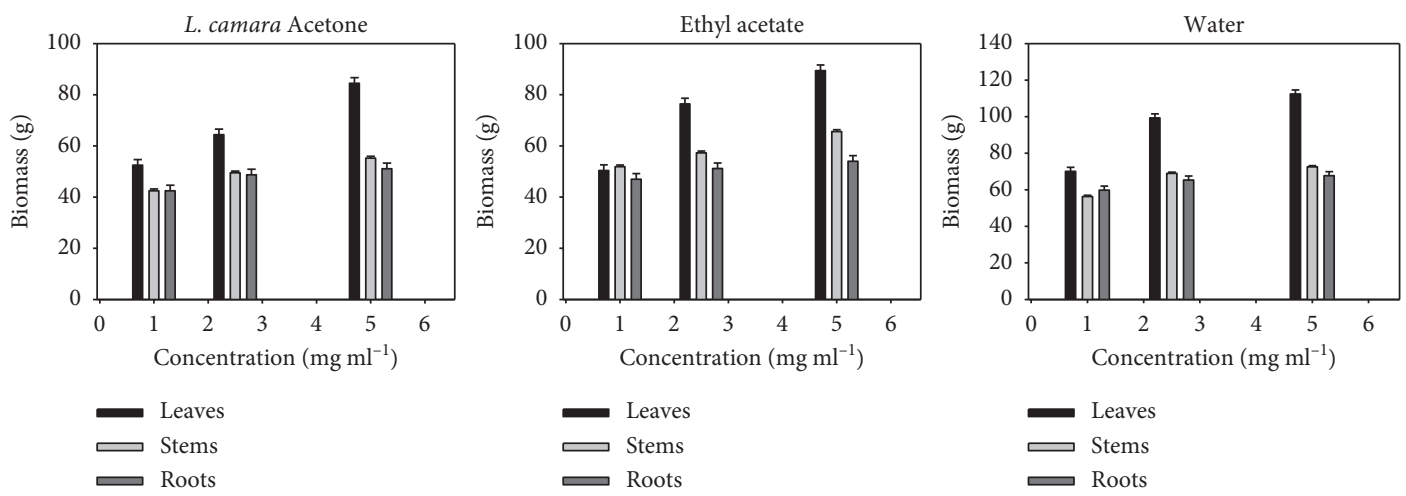

$$
\begin{aligned}
& \text { Leaves } \\
& \text { Stems } \\
& \text { Roots }
\end{aligned}
$$

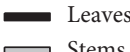

Stems

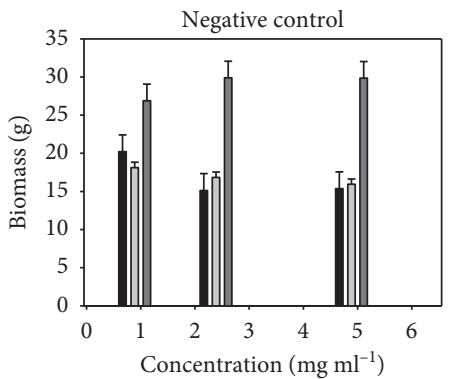

$$
\text { Leaves }
$$

Figure 6: Effect of botanical extracts on the leaves, stem, and roots biomass on S. esculentum plants after innoculation with $P$. infestans under glasshouse conditions at the University of Zimbabwe. Error bars represent LSD at $p \leq 0.05$ of a mean pooled from three replications. 

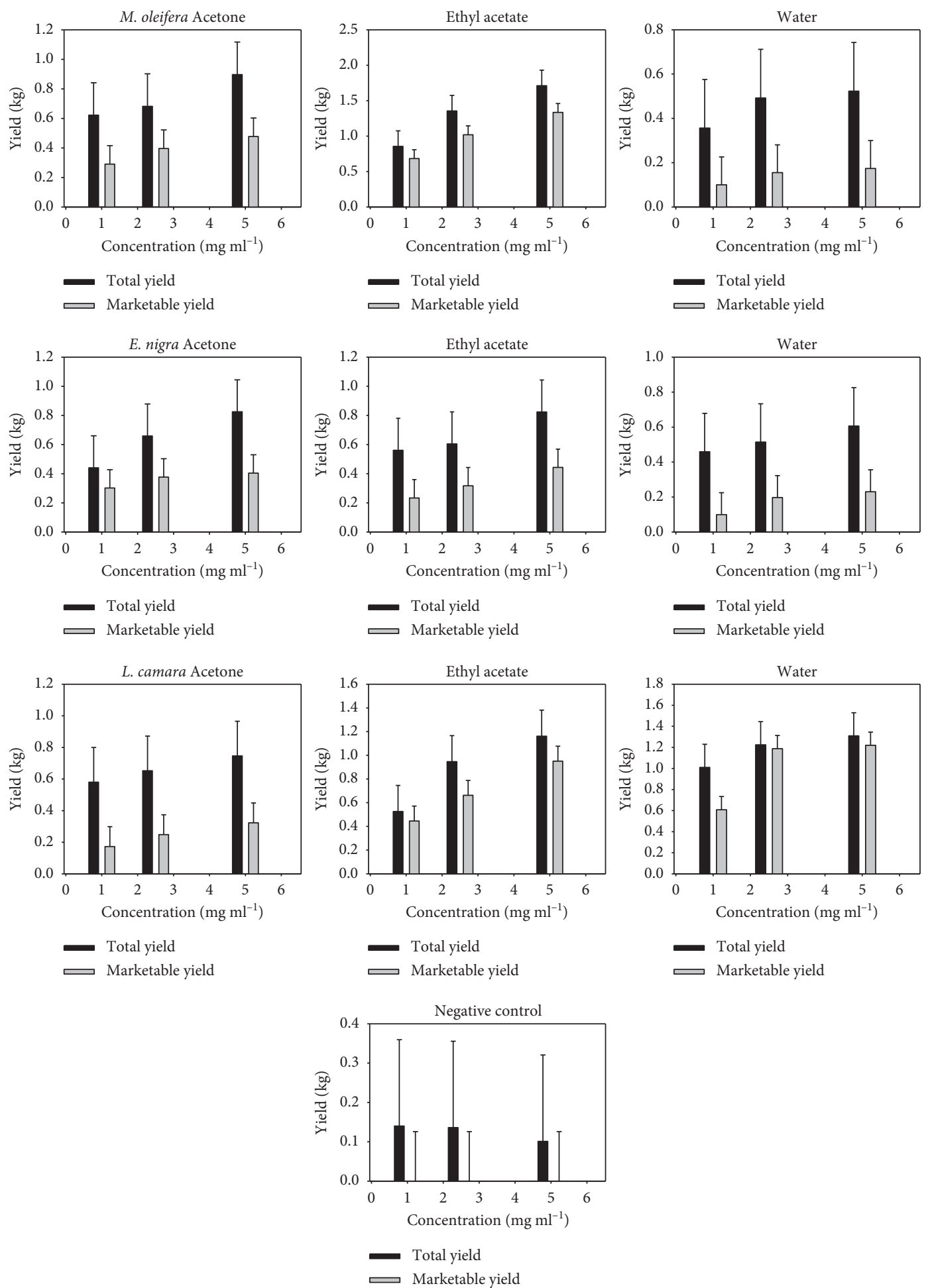

Figure 7: Effect of botanical extracts on the yield of S. esculentum plants after innoculation with $P$. infestans under glasshouse conditions at the University of Zimbabwe. Error bars represent LSD at $p \leq 0.05$ of a mean pooled from three replications.

which had a match score of above $90 \%$ which suggest that they were the major compounds in E. nigra ethyl acetate extracts (Table 6). On the other hand, 3-furaldehyde was detected in E. nigra water extract with a match score above $95 \%$.

Furfural, cyclopentasiloxane, decamethyl, and Guanidine which had a match score above $90 \%$ were detected in
L. camara acetone extract (Table 7). On the other hand, cyclopentasiloxane, decamethyl- were detected with a match score above $90 \%$ in both methyl acetate and water extracts. In addition, the probability that 2-pentanone, 4-hydroxy-4methyl was present in the L. camara extract was above $95 \%$ (Table 7). 


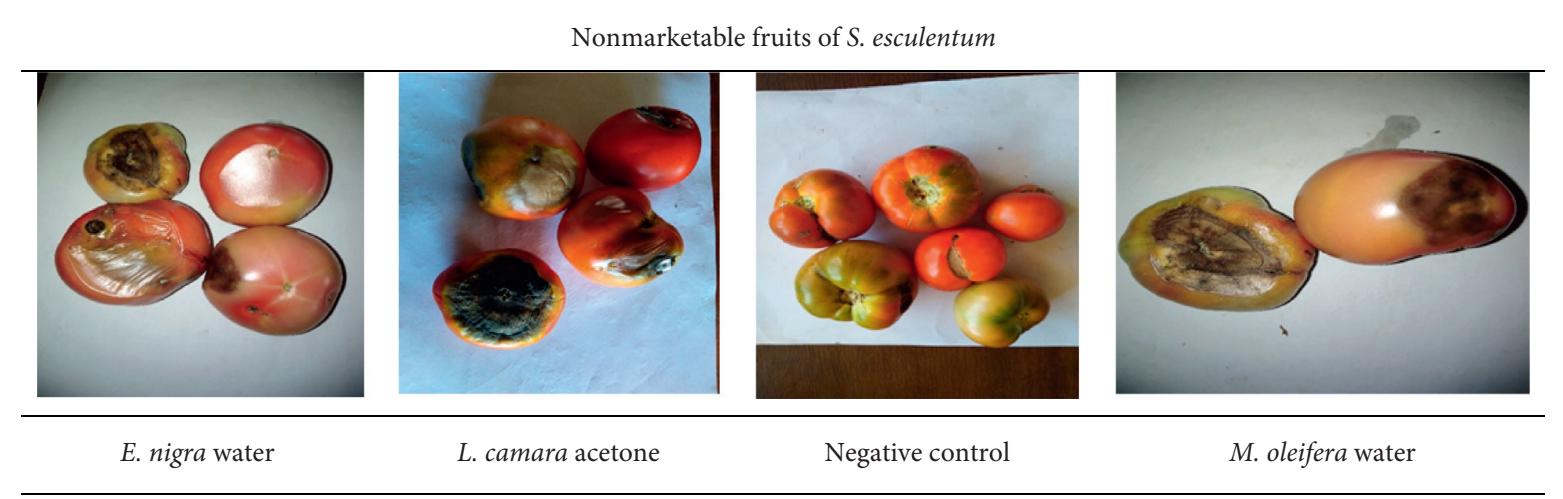

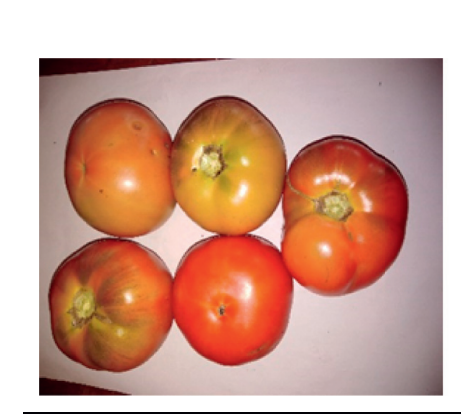

M. oleifera ethyl acetate

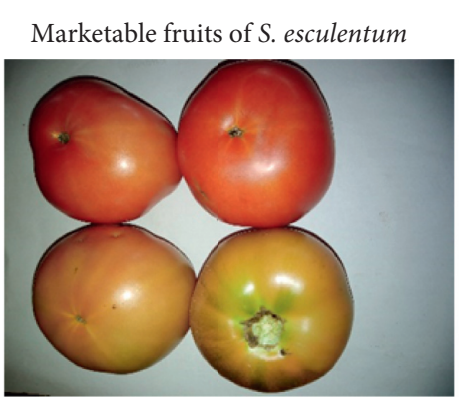

E. nigra ethyl acetate

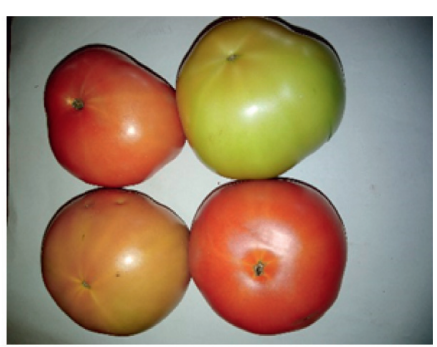

L. camara water

Figure 8: Effect of different botanical extracts on S. esculentum fruit quality.

\section{Discussion}

4.1. Effect of Botanical Extracts on Radial Growth and Percentage Inhibition of $P$. infestans In Vitro. Fungal growth is measured using radial growth and percentage inhibition. The findings obtained from this study showed that botanical extracts of $M$. oleifera, E. nigra, and L. camara contain antifungal compounds which reduced radial growth and increased percent inhibition of $P$. infestans. High percentage inhibition was recorded in L. camara water, M. oleifera ethyl acetate, and E. nigra ethyl acetate extracts.

Reduced mycelial growth of $P$. infestans by $L$. camara seed and leaf extracts was also reported by Raza et al. [16]. Reduced development of $P$. infestans on $S$. esculentum plants inoculated with the pathogen could be attributed to the presence of antifungal compounds in the botanical extracts. Nagar et al. [1] reported that these antifungal compounds bind and penetrate the surface of $P$. infestans resulting in denaturation of enzymes and proteins. This also concurs with the work done by Ghannoum and Rice [17] on imidazole derivatives (such as miconazole, econazole, and ketoconazole) which had a complex mode of action, inhibiting synthesis of several membrane-bound enzymes as well as membrane lipid biosynthesis of pathogens.

In contrast, $M$. oleifera water, E. nigra water, and L. camara acetone extracts recorded low mycelium inhibition. Lower inhibition by aqueous extracts reported in their study can be attributed to the fact that oil antifungal compounds do not dissolve in water. This result is in line with the findings of Bandor et al. [18] where Labanese weed (Urtica dioica) water extracts recorded low mycelium inhibition. The maximal percent inhibition of $P$. infestans was observed on $5 \mathrm{mg} \mathrm{ml}^{-1}$ botanical concentration. It is postulated that high extract concentration of $5 \mathrm{mg} \mathrm{ml}^{-1}$ effectively inhibited mycelial growth and development of $P$. infestans. The findings concur with those of Nagar et al. [1] who reported that willow (Salix species) extracts at high concentration effectively increased percent inhibition on $P$. infestans.

4.2. Effect of Botanical Extracts on the Defence Enzymes. There was a significant increase in defence enzyme activity of PPO, PAL, and POD in plants treated with M. oleifera ethyl acetate, L. camara water, and E. nigra ethyl acetate extracts. An increase in enzyme activity could be be attributed to the fact that $M$. oleifera ethyl acetate, $L$. camara water, and E. nigra acetone and ethyl acetate extracts contain compounds that have a stimulatory effect on the activity of PPO, PAL, and POD which can protect plant cells from lipid peroxidation as was reported by other authors $[19,20]$. Murimwa et al. [21] reported an increase in POD activity when sorghum (Sorghum bicolor L. Moench) aqueous extracts were sprayed on sesame (Sesamum indicum L.), blackjack (Bidens pilosa L.), and goose grass (Eleusine indica L. Gaertn) varieties and selected weeds. These findings concur with the work of Singh [22] who reported an increase in defence enzyme activity after application of bitter gourd (M. charantia) extracts in S. esculentum.

The effects of PPO, PAL, and POD activities were also reported by Ngadze et al. [14] as having the ability to impart 

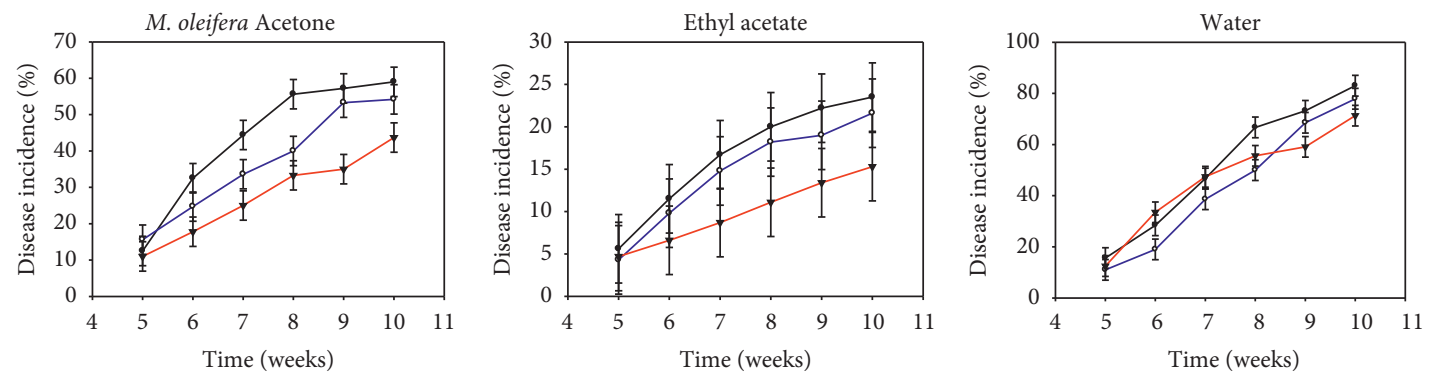

Concentration

- $1 \mathrm{mg} \mathrm{ml}^{-1}$

$\longrightarrow 2.5$

$\longrightarrow 5$

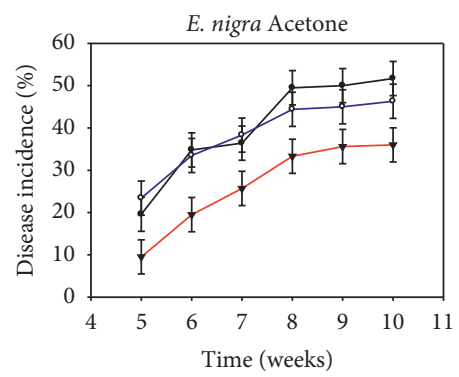

$$
\begin{aligned}
& \text { Concentration } \\
& \longrightarrow \quad 1 \mathrm{mg} \mathrm{ml}^{-1} \\
& \longrightarrow 2.5
\end{aligned}
$$

$\longrightarrow 5$
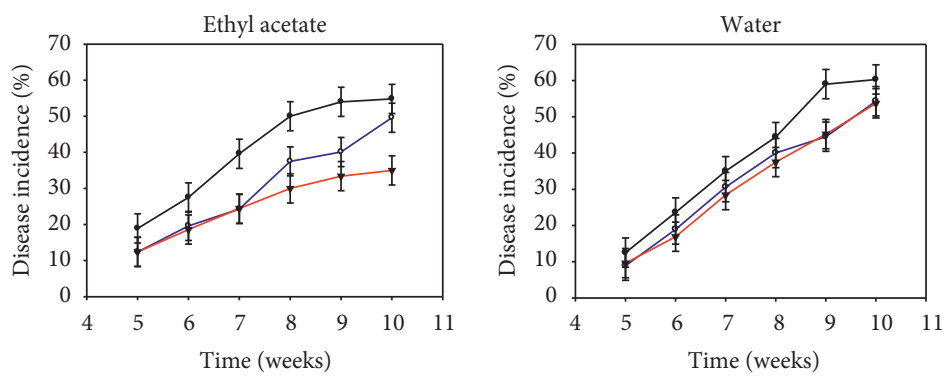

Concentration

$\longrightarrow 1 \mathrm{mg} \mathrm{ml}^{-1}$

$\longrightarrow 2.5$

Concentration

— $1 \mathrm{mg} \mathrm{ml}^{-1}$

Concentration

$\multimap 2.5$

$\longrightarrow 1 \mathrm{mg} \mathrm{ml}^{-1}$

$\because 2.5$

$\longrightarrow 5$
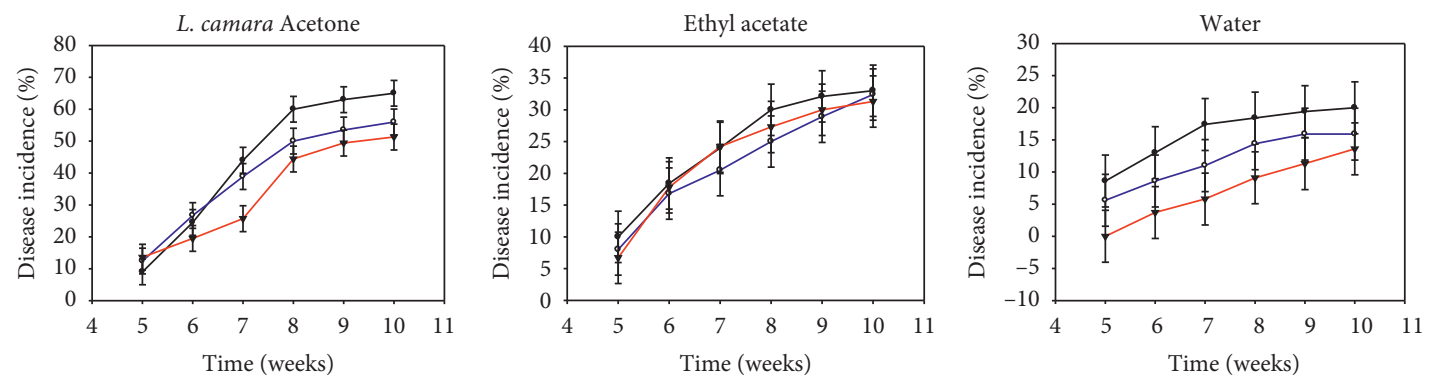

$$
\begin{aligned}
& \text { Concentration } \\
& \longrightarrow \quad 1 \mathrm{mg} \mathrm{ml}^{-1} \\
& \square \quad 2.5 \\
& \square \quad 5
\end{aligned}
$$

$$
\begin{aligned}
& \text { Concentration } \\
& \square \quad 1 \mathrm{mg} \mathrm{ml}^{-1} \\
& \square \quad 2.5
\end{aligned}
$$

Concentration

$\longrightarrow 1 \mathrm{mg} \mathrm{ml}^{-1}$

$\longrightarrow 2.5$

$\rightarrow 5$

$\rightarrow 5$

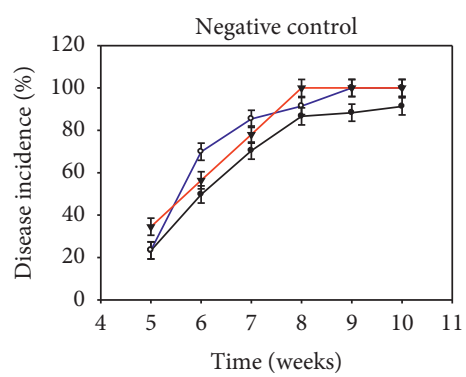

$$
\begin{aligned}
& \text { Concentration } \\
& \longrightarrow \quad 1 \mathrm{mg} \mathrm{ml}^{-1} \\
& \longrightarrow \quad 2.5 \\
& \longrightarrow 5
\end{aligned}
$$

Figure 9: Effect of botanical extracts on the disease incidence (\%) on S. esculentum plants after innoculation with $P$. infestans under glasshouse conditions at the University of Zimbabwe. Error bars represent LSD at $p \leq 0.05$ of a mean pooled from three replications. 

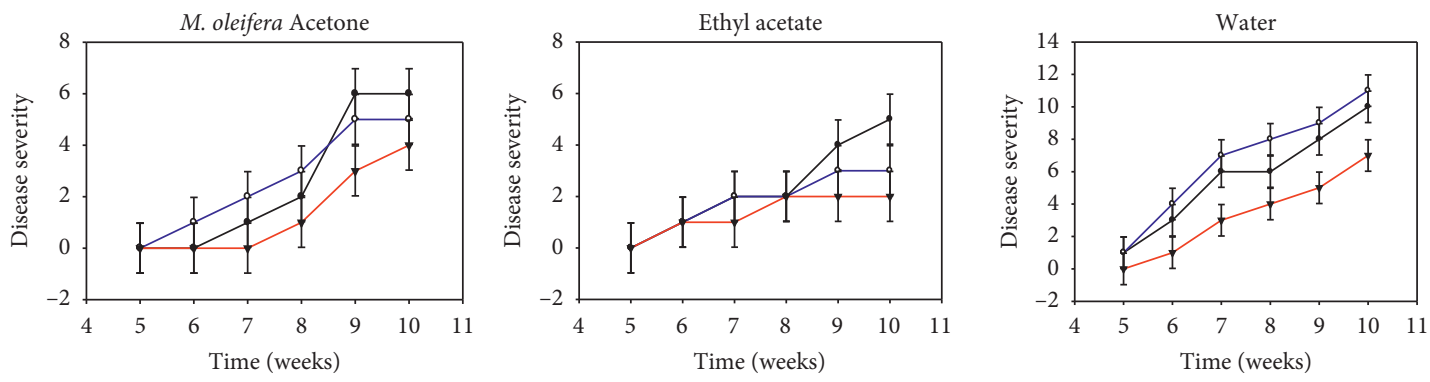

Concentration

$\multimap 0.5 \mathrm{mg} \mathrm{ml}^{-1}$

$\rightarrow 2.5$

$\rightarrow 5$

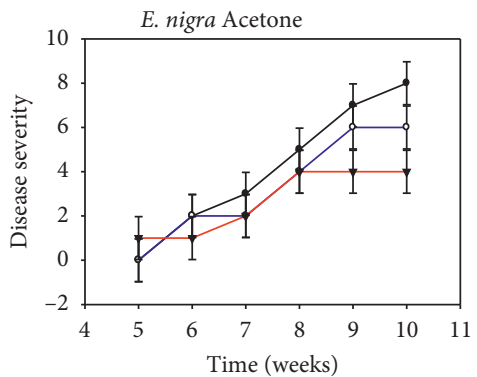

Concentration

$\rightarrow 0.5 \mathrm{mg} \mathrm{ml}^{-1}$

$\multimap 2.5$

$\longrightarrow 5$

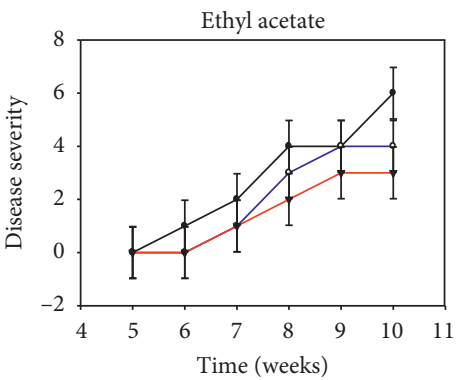

$\rightarrow 0.5 \mathrm{mg} \mathrm{ml}^{-1}$

$\longrightarrow 2.5$

$\rightarrow 5$

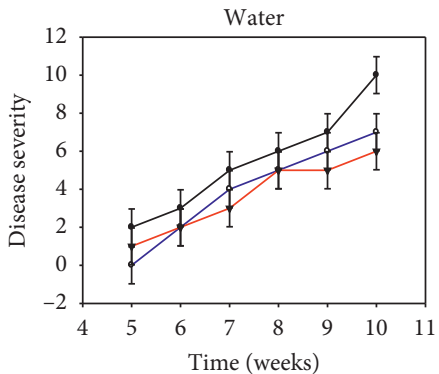

Concentration

$\longrightarrow 0.5 \mathrm{mg} \mathrm{ml}^{-1}$

$\multimap 2.5$

$\rightarrow 5$

Concentration

$\longrightarrow 0.5 \mathrm{mg} \mathrm{ml}^{-1}$

$\multimap 2.5$

$\checkmark 5$
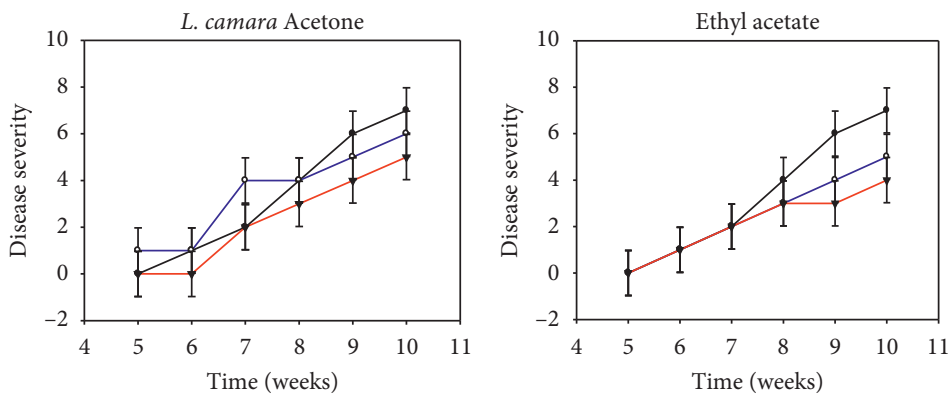

Concentration

$\rightarrow 0.5 \mathrm{mg} \mathrm{ml}^{-1}$

$\multimap 2.5$

$\checkmark 5$
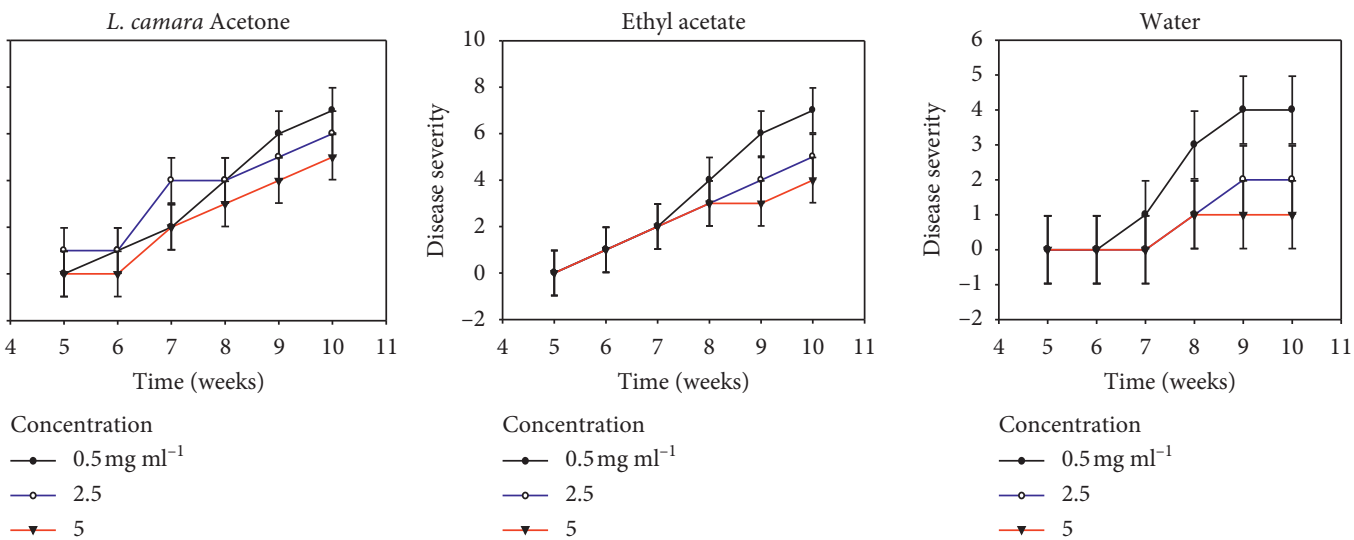

Concentration

$\longrightarrow 0.5 \mathrm{mg} \mathrm{ml}^{-1}$

$\multimap 2.5$

Concentration

$\longrightarrow 0.5 \mathrm{mg} \mathrm{ml}^{-1}$

$\because 2.5$

$\longrightarrow 5$

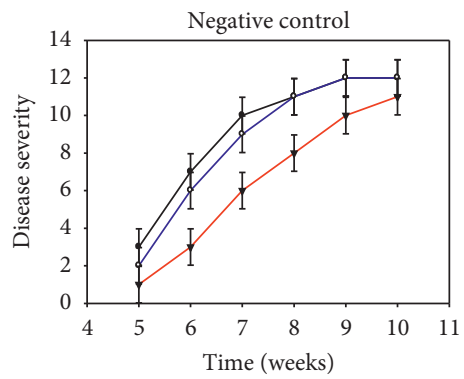

$\longrightarrow 5$

Concentration

$\longrightarrow 0.5 \mathrm{mg} \mathrm{ml}^{-1}$

$\multimap 2.5$

$\rightarrow 5$

FIGURE 10: Effect of botanical extracts on disease severity of $S$. esculentum plants after innoculation with $P$. infestans under glasshouse conditions at the University of Zimbabwe. Error bars represent LSD at $p \leq 0.05$ of a mean pooled from three replications. 
TABle 5: Mass spectra data and tentative identification of the antifungal compounds in M. oleifera extract.

\begin{tabular}{|c|c|c|c|}
\hline Solvent & Compound name & Formula & Match score \\
\hline Acetone & $\begin{array}{c}\text { Cyclopentasiloxane, decamethyl- } \\
\text { Cyclobutanone, 2-methyl- } \\
\text { 1H-1,2,4-Triazol-3-amine, 5-methyl- } \\
\text { Nonanal } \\
\text { Propanal, 2-methyl- }\end{array}$ & $\begin{array}{c}\mathrm{C}_{10} \mathrm{H}_{30} \mathrm{O}_{5} \mathrm{Si}_{5} \\
\mathrm{C}_{5} \mathrm{H}_{8} \mathrm{O} \\
\mathrm{C}_{3} \mathrm{H}_{6} \mathrm{~N}_{4} \\
\mathrm{C}_{9} \mathrm{H}_{18} \mathrm{O} \\
\mathrm{C}_{4} \mathrm{H}_{8} \mathrm{O}\end{array}$ & $\begin{array}{c}90.1 \\
86 \\
81.4 \\
82.9 \\
81.8\end{array}$ \\
\hline Ethyl acetate & $\begin{array}{c}\text { Ethanol, 2-ethoxy- } \\
\text { 5-Methyl-4-(trifluoromethyl)pyrido[4,3- } \\
\text { 1H-Tetrazole } \\
\text { 4-Aminoheptane } \\
\text { 9-(2-(5-Methyl-2-pyridyl)ethyl)-6-methyl- } \\
\text { 2-Ethyl-2-phenyl-1,3-benzodioxole } \\
\text { 3,4-Dihydroxyphenylglycol, 4TMS derivative }\end{array}$ & $\begin{array}{c}\mathrm{C}_{4} \mathrm{H}_{10} \mathrm{O}_{2} \\
\mathrm{C}_{9} \mathrm{H}_{6} \mathrm{~F}_{3} \mathrm{~N}_{3} \\
\mathrm{CH}_{2} \mathrm{~N}_{4} \\
\mathrm{C}_{7} \mathrm{H}_{17} \mathrm{~N} \\
\mathrm{C}_{21} \mathrm{H}_{24} \mathrm{~N}_{2} \\
\mathrm{C}_{15} \mathrm{H}_{14} \mathrm{O}_{2} \\
\mathrm{C}_{20} \mathrm{H}_{42} \mathrm{O}_{4} \mathrm{Si}_{4} \\
\end{array}$ & $\begin{array}{l}85.7 \\
80.9 \\
80.1 \\
81.2 \\
81.8 \\
81.4 \\
89.7 \\
\end{array}$ \\
\hline Water & $\begin{array}{c}\text { Cyclopentasiloxane, decamethyl- } \\
\text { Octanal } \\
\text { Cyclohexasiloxane, dodecamethyl- } \\
\text { Nonanal } \\
\text { Isopropylcyclobutane } \\
\text { Oxalic acid, butyl cyclobutyl ester } \\
\text { Acenaphthene } \\
\text { Biphenyl } \\
\text { Acenaphthene } \\
\text { Ethanol, 2-ethoxy- } \\
\text { Ethyl diazoacetate }\end{array}$ & $\begin{array}{c}\mathrm{C}_{10} \mathrm{H}_{30} \mathrm{O}_{5} \mathrm{Si}_{5} \\
\mathrm{C}_{8} \mathrm{H}_{16} \mathrm{O} \\
\mathrm{C}_{12} \mathrm{H}_{36} \mathrm{O}_{6} \mathrm{Si}_{6} \\
\mathrm{C}_{9} \mathrm{H}_{18} \mathrm{O} \\
\mathrm{C}_{7} \mathrm{H}_{14} \\
\mathrm{C}_{10} \mathrm{H}_{16} \mathrm{O}_{4} \\
\mathrm{C}_{12} \mathrm{H}_{10} \\
\mathrm{C}_{12} \mathrm{H}_{10} \\
\mathrm{C}_{12} \mathrm{H}_{10} \\
\mathrm{C}_{4} \mathrm{H}_{10} \mathrm{O}_{2} \\
\mathrm{C}_{4} \mathrm{H}_{6} \mathrm{~N}_{2} \mathrm{O}_{2}\end{array}$ & $\begin{array}{c}87.9 \\
84 \\
86.5 \\
83.2 \\
87.3 \\
89.7 \\
80.1 \\
90.8 \\
91.5 \\
82.5 \\
86.6\end{array}$ \\
\hline
\end{tabular}

TABLE 6: Mass spectra data and tentative identification of the antifungal compounds in E. nigra extract.

\begin{tabular}{|c|c|c|c|}
\hline Solvent & Compound name & Formula & Match score \\
\hline \multirow{9}{*}{ Acetone } & Cyclopentasiloxane, decamethyl- & $\mathrm{C}_{10} \mathrm{H}_{30} \mathrm{O}_{5} \mathrm{Si}_{5}$ & 82.1 \\
\hline & 1,2,4,5-Tetrazine, 3,6-bis(1,1-dimethylethyl)- & $\mathrm{C}_{10} \mathrm{H}_{18} \mathrm{~N}_{4}$ & 82.2 \\
\hline & Nonanal & $\mathrm{C}_{9} \mathrm{H}_{18} \mathrm{O}$ & 83.8 \\
\hline & Benzene, nitro- & $\mathrm{C}_{6} \mathrm{H}_{5} \mathrm{NO}_{2}$ & 85.4 \\
\hline & Dodecanamide & $\mathrm{C}_{12} \mathrm{H}_{25} \mathrm{NO}$ & 80.4 \\
\hline & 1H-Benzimidazole, 1,2-diphenyl- & $\mathrm{C}_{19} \mathrm{H}_{14} \mathrm{~N}_{2}$ & 86.4 \\
\hline & 3-Pyridinecarboxamide, N-phenyl- & $\mathrm{C}_{12} \mathrm{H}_{10} \mathrm{~N}_{2} \mathrm{O}$ & 83.4 \\
\hline & 1H-1,3-Diazepine, 4,5,6,7-tetrahydro-2-methyl- & $\mathrm{C}_{6} \mathrm{H}_{12} \mathrm{~N}_{2}$ & 81.1 \\
\hline & Silane, diethylpentadecyloxytetradecyloxy- & $\mathrm{C}_{33} \mathrm{H}_{70} \mathrm{O}_{2} \mathrm{Si}$ & 83 \\
\hline \multirow{8}{*}{ Ethyl acetate } & Furfural & $\mathrm{C}_{5} \mathrm{H}_{4} \mathrm{O}_{2}$ & 90.1 \\
\hline & Eucalyptol & $\mathrm{C}_{10} \mathrm{H}_{18} \mathrm{O}$ & 93 \\
\hline & Ethanone, 1-(2-furanyl)- & $\mathrm{C}_{6} \mathrm{H}_{6} \mathrm{O}_{2}$ & 83 \\
\hline & 1-(3H-Imidazol-4-yl)-ethanone & $\mathrm{C}_{5} \mathrm{H}_{6} \mathrm{~N}_{2} \mathrm{O}$ & 80.9 \\
\hline & 2-Oxabicyclo[2.2.2] octan-6-ol, 1,3,3-trimethyl- & $\mathrm{C}_{10} \mathrm{H}_{18} \mathrm{O}_{2}$ & 81.8 \\
\hline & 1,3-Cyclobutanedione, 2,2,4,4-tetramethyl- & $\mathrm{C}_{8} \mathrm{H}_{12} \mathrm{O}_{2}$ & 82.6 \\
\hline & 1,2,5-Thiadiazole & $\mathrm{C}_{2} \mathrm{H}_{2} \mathrm{~N}_{2} \mathrm{~S}$ & 80.7 \\
\hline & Dodecanamide & $\mathrm{C}_{12} \mathrm{H}_{25} \mathrm{NO}$ & 81.8 \\
\hline \multirow{6}{*}{ Water } & 1-Hexen-3-one & $\mathrm{C}_{6} \mathrm{H}_{10} \mathrm{O}$ & 87.3 \\
\hline & 3-Furaldehyde & $\mathrm{C}_{5} \mathrm{H}_{4} \mathrm{O}_{2}$ & 98.3 \\
\hline & Propane, 1-isocyanato- & $\mathrm{C}_{4} \mathrm{H}_{7} \mathrm{NO}$ & 83.1 \\
\hline & Dodecanamide & $\mathrm{C}_{12} \mathrm{H}_{25} \mathrm{NO}$ & 81.5 \\
\hline & Isopropyl alcohol & $\mathrm{C}_{3} \mathrm{H}_{8} \mathrm{O}$ & 83.7 \\
\hline & 4-(2-Methoxyethyl)-2-methylphenol & $\mathrm{C}_{10} \mathrm{H}_{14} \mathrm{O}_{2}$ & 81 \\
\hline
\end{tabular}

resistance to soft rot in potatoes (S. tuberosum). The increase in POD activity was very crucial as the first line of defence because it produces lignin [23] from oxidation of hydroxycinnamyl alcohol, and PAL enhances production of cinnamic acid [24]. It was found in an earlier research work that the covalent bonding nucleophilic substituents of amino acids and proteins by PPO-derived quinones are thought to exert an antinutritive defence against insects and pathogens [25].

The compounds cement the cell walls of host plant so as to inhibit the entry of the pathogen. Eventhough the $S$. esculentum plants were inoculated with $P$. infestans, these defence enzymes had the ability to detoxify the reactive oxygen species (ROS) which were synthesised when the plants 
TABle 7: Mass spectra data and tentative identification of the antifungal compounds in L. camara extract.

\begin{tabular}{|c|c|c|c|}
\hline Solvent & Compound name & Formula & Match score \\
\hline \multirow{11}{*}{ Acetone } & Furfural & $\mathrm{C}_{5} \mathrm{H}_{4} \mathrm{O}_{2}$ & 92.9 \\
\hline & Cyclopentasiloxane, decamethyl- & $\mathrm{C}_{10} \mathrm{H}_{30} \mathrm{O}_{5} \mathrm{Si}_{5}$ & 90.3 \\
\hline & Octanal & $\mathrm{C}_{8} \mathrm{H}_{16} \mathrm{O}$ & 82.3 \\
\hline & Piperazine, 1,4-dinitro- & $\mathrm{C}_{4} \mathrm{H}_{8} \mathrm{~N}_{4} \mathrm{O}_{4}$ & 92.4 \\
\hline & Cyclohexasiloxane, dodecamethyl- & $\mathrm{C}_{12} \mathrm{H}_{36} \mathrm{O}_{6} \mathrm{Si}_{6}$ & 93.4 \\
\hline & Nonanal & $\mathrm{C}_{9} \mathrm{H}_{18} \mathrm{O}$ & 86.6 \\
\hline & Dodecanamide & $\mathrm{C}_{12} \mathrm{H}_{25} \mathrm{NO}$ & 82.9 \\
\hline & Guanidine & $\mathrm{CH}_{5} \mathrm{~N}_{3}$ & 90 \\
\hline & Ethanol, 2-ethoxy- & $\mathrm{C}_{4} \mathrm{H}_{10} \mathrm{O}_{2}$ & 81.5 \\
\hline & Ethanol, 2-ethoxy- & $\mathrm{C}_{4} \mathrm{H}_{10} \mathrm{O}_{2}$ & 81.7 \\
\hline & Isolan & $\mathrm{C}_{10} \mathrm{H}_{17} \mathrm{~N}_{3} \mathrm{O}_{2}$ & 88.8 \\
\hline \multirow{11}{*}{ Ethyl acetate } & 1-n-Butoxy-2,3-dimethyldiaziridine & $\mathrm{C}_{8} \mathrm{H}_{17} \mathrm{NO}$ & 81.3 \\
\hline & Cyclopentasiloxane, decamethyl- & $\mathrm{C}_{10} \mathrm{H}_{30} \mathrm{O}_{5} \mathrm{Si}_{5}$ & 90.1 \\
\hline & Cyclohexasiloxane, dodecamethyl- & $\mathrm{C}_{12} \mathrm{H}_{36} \mathrm{O}_{6} \mathrm{Si}_{6}$ & 87.4 \\
\hline & 2,3,4-Trihydroxybenzaldehyde & $\mathrm{C}_{7} \mathrm{H}_{6} \mathrm{O}_{4}$ & 80.6 \\
\hline & 1-Propene, 2-methoxy- & $\mathrm{C}_{4} \mathrm{H}_{8} \mathrm{O}$ & 80.2 \\
\hline & 2-Butanol & $\mathrm{C}_{4} \mathrm{H}_{10} \mathrm{O}$ & 84.8 \\
\hline & Dodecanamide & $\mathrm{C}_{12} \mathrm{H}_{25} \mathrm{NO}$ & 84.5 \\
\hline & Acetaldoxime & $\mathrm{C}_{2} \mathrm{H}_{5} \mathrm{NO}$ & 83.7 \\
\hline & Ethyl diazoacetate & $\mathrm{C}_{4} \mathrm{H}_{6} \mathrm{~N}_{2} \mathrm{O}_{2}$ & 85.4 \\
\hline & Ethanol, 2-ethoxy- & $\mathrm{C}_{4} \mathrm{H}_{10} \mathrm{O}_{2}$ & 85.1 \\
\hline & Ethanol, 2-ethoxy- & $\mathrm{C}_{4} \mathrm{H}_{10} \mathrm{O}_{2}$ & 81.4 \\
\hline \multirow{9}{*}{ Water } & 2-Pentanone, 4-hydroxy-4-methyl- & $\mathrm{C}_{6} \mathrm{H}_{12} \mathrm{O}_{2}$ & 95.9 \\
\hline & Cyclopentasiloxane, decamethyl- & $\mathrm{C}_{10} \mathrm{H}_{30} \mathrm{O}_{5} \mathrm{Si}_{5}$ & 91.1 \\
\hline & Cyclohexasiloxane, dodecamethyl- & $\mathrm{C}_{12} \mathrm{H}_{36} \mathrm{O}_{6} \mathrm{Si}_{6}$ & 88.9 \\
\hline & Nonanal & $\mathrm{C}_{9} \mathrm{H}_{18} \mathrm{O}$ & 86 \\
\hline & Ethanol, 2-ethoxy- & $\mathrm{C}_{4} \mathrm{H}_{10} \mathrm{O}_{2}$ & 86 \\
\hline & Dodecanamide & $\mathrm{C}_{12} \mathrm{H}_{25} \mathrm{NO}$ & 82.5 \\
\hline & Formic acid, ethenyl ester & $\mathrm{C}_{3} \mathrm{H}_{4} \mathrm{O}_{2}$ & 85.4 \\
\hline & Pentanamide & $\mathrm{C}_{5} \mathrm{H}_{11} \mathrm{NO}$ & 82.7 \\
\hline & (S)-(+)-2-Amino-3-methyl-1-butanol & $\mathrm{C}_{5} \mathrm{H}_{13} \mathrm{NO}$ & 84.6 \\
\hline
\end{tabular}

were stressed by $P$. infestans as was also reported by Nunes et al. [19]. Although L. camara water extract reduced growth and development of $P$. infestans in vivo, there was low enzyme activity for all the defence enzymes evaluated. Reduced disease development in plants treated with $L$. camara botanical extracts could be a result of the direct effect of allelochemicals on $P$. infestans rather than toxicant-induced stimulation of defence enzyme activity. Defence enzyme activity was lower in $M$. oleifera water, E. nigra water, and L. camara acetone extracts compared to $M$. oleifera ethyl acetate, E. nigra ethyl acetate, and $L$. camara water extracts.

4.3. Effect of Botanical Extracts on Disease Incidence and Late Blight Disease Severity on S. esculentum. The study suggested that L. camara water, M. oleifera ethyl acetate, and E. nigra acetone extracts reduced disease incidence and severity. According to Goufo et al. [4], reduced $S$. esculentum late blight disease incidence and severity could be attributed to the inhibitory effect of antifungal compounds produced by these botanical extracts. Moreover, reduced disease incidence and severity on plants treated with botanicals may be due to the activation of plant defence enzymes by the four botanical extracts which detoxify the ROS produced by the S. esculentum plants infected by $P$. infestans $[20,23]$.
In addition, S. esculentum can produce defence compounds after application of $M$. oleifera extracts resulting in an increased amount of sinigrin which is important in the defence system against late blight on $S$. esculentum [26, 27]. These results concur with the findings of Goufo et al. [4], where floss flower (A. houstonianum), horsewood (C. anisata), and fish poison (T. vogelii) inhibited $P$. infestans development.

Highest disease incidence and severity were recorded in M. oleifera water, E. nigra water, and L. camara acetone extracts. These botanical extracts had less inhibitory effects on late blight because they had less allelopathic potency, and there was low enzyme activity for all the defence enzymes evaluated to reduce the development of late blight. Interestingly, all the extracts tested reduced disease incidence and disease severity compared to the negative control.

4.4. Effect of Botanical Extracts on S. esculentum Yield. The application of the botanical extracts significantly increased marketable yield and total yield of S. esculentum fruits. This effect showed that botanical extracts did not cause phytotoxic damage to S. esculentum fruits. This can be attributed to the fact that compounds in these botanical extracts quickly inhibit growth and development of late blight. However, there was low marketable and total yield 
obtained in S. esculentum plants treated with M. oleifera water, E. nigra water, and L. camara acetone extracts. These botanical extracts had less inhibitory effects on late blight because they had less allelopathic effects to reduce the development of late blight.

4.5. Gas Chromatography-Mass Spectrometric Analysis of Antifungal Compounds in Botanical Extracts. The antifungal compounds in M. oleifera, E. nigra, and L. camara using acetone, ethyl acetate, and water as extraction solvents were tentatively identified using GC-MS. These antifungal compounds were isolated and eluted at a retention time interval from 0 to 3.4 minutes. Interestingly, most of the antifungal compounds found in the study have not yet been documented especially in M. oleifera. The difference in the type of compounds isolated could be attributed to the differences in extraction methods that were used.

Cyclopentasiloxane and decamethyl were found mostly in E. nigra and L. camara extracts across all the solvents. In contrast, Patil et al. [28] and Shriniwas and Subhash [29] reported that Eucalyptus species and L. camara had a higher constituency of terpenes. The variation in different antifungal compounds detected in botanical extracts can be influenced by extraction solvent and the method of extraction. According to Rouhallah and Choong [30], proficiency in sensing and responding to these antifungal compounds increases plant ecological advantage and ability to survive in competitive environments, with respect to plant-pathogen interactions. So, from the antifungal compounds which were extracted from these botanical extracts using different solvents, the antifungal compounds had a lethal effect on the growth and establishment of $P$. infestans.

These botanical extracts are environmentally friendly as they are nonpollutive, largely nonphytotoxic, and have no residual effects, thus being readily biodegradable, renewable and inexhaustible [5], hence playing a crucial role in smart agriculture, as it can be used as a management tool on late blight resistance. For the researchers, there is still a need to isolate, identify, and quantify the amount of active ingredients in the botanical extracts that exhibited antifungal activity using pure standards of these antifungal compounds that were detected in this study [31].

\section{Conclusion}

Based on the results obtained in this study, it can be concluded that $M$. oleifera ethyl acetate, E. nigra ethyl acetate, and L. camara water extracts reduced radial growth and increased percent inhibition in vitro. Green house evaluation showed that $M$. oleifera ethyl acetate, E.nigra ethyl acetate, and L. camara acetone and water extracts increase economic and total yield and reduce disease incidence and severity in S. esculentum plants. The PPO, PAL, and POD enzymatic activity increased after the application of botanical extracts on S. esculentum plants. Overall, L. camara water, $M$. oleifera ethyl acetate, and E. nigra ethyl acetate extracts effectively suppressed $P$. infestans.

\section{Data Availability}

The data used to support the findings of this study are available from the corresponding author upon request.

\section{Conflicts of Interest}

The authors declare that they have no conflicts of interest.

\section{Acknowledgments}

This research was funded through a post doctoral grant provided by Carnegie Cooperation of New York through the Regional Universities Forum for Capacity Building in Agriculture (RUFORUM). The authors also thank DAAD for the MSc in-country scholarship.

\section{References}

[1] D. Nagar, S. K. Biswas, M. Singh, and J. Singh, "Efficacy of different plant extracts against Phytophthora infestans (Mont.) de Bary," International Journal of Current Microbiology and Applied Science, vol. 6, pp. 412-417, 2017.

[2] G. Y. J. Hubert, N. Julienne, D. D. Charles, P. T. Sandrine, F. F. Romain, and A. Z. P. Henry, "Antifungal potential and phytochemical analysis of extracts from seven Cameroonian plants against late blight pathogen Phytophthora infestans," International Journal of Current Microbiology and Applied Science, vol. 2, pp. 140-154, 2013.

[3] L. C. Yadav, A. A. Lal, S. S. Kakraliya, M. R. Bajiya, and M. Sheshma, "Efficacy of certain bio-agents and plant extracts against lateblight (Phytophthora infestans) of tomato (Lycopersicon esculentum L.)," International Journal of Current Microbiology and Applied Science, vol. 6, pp. 779-784, 2017.

[4] P. Goufo, D. A. Fontem, and D. Ngnokam, "Evaluation of plant extracts for tomato late blight control in Cameroon," New Zealand Journal Crop and Horticultural Science, vol. 38, pp. 171-176, 2010.

[5] J. W. Muthomi, G. M. W. Lengai, M. J. Wagacha, and R. D. Narla, "In vitro activity of plant extracts against some important plant pathogenic fungi of tomato," Australian Journal of Crop Science, vol. 11, pp. 683-689, 2017.

[6] D. Spc, "In Vivo evaluation of fungicides for the management of lateblight of tomato," Journal of Plant Pathology and Microbiology, vol. 8, pp. 6-11, 2017.

[7] S. Mahajan, A Gupta, and R. Sharma, "Manuscript reviewers 2015," Hastings Center Report, vol. 45, no. 6, p. 51, 2015.

[8] E. Ngadze, "Protection de la maternité," Primary Care, vol. 14, no. 12, p. 198, 2014.

[9] E. S. G. Mizubuti, V. L. Júnior, and G. A. Forbes, "Management of lateblight with alternative products," Pest Technology, vol. 1, pp. 11-17, 2007.

[10] D. Sadana and N. Didwania, "Bioefficacy of fungicides and plant extracts against Alternaria solani causing early blight of tomato," International Conference of Plant Marine and Environmental, Science, vol. 1, no. 2, pp. 38-42, 2015.

[11] T. Bohinc, D. Znidarcic, and S. Trdan, "Comparison of field efficacy of four natural fungicides and metiram against late blight (Phytophthora infestans Mont. de Bary) on tomato," Horticultural Science, vol. 42, pp. 215-218, 2015.

[12] J. I. G. Masangwa, T. A.S. Aveling, and Q. Kritzinger, "Screening of plant extracts for antifungal activities against Colletotrichum species of common bean (Phaseolus vulgaris 
L.) and cowpea (Vigna unguiculata (L.) Walp)," Journal of Agricultural Science, vol. 6, pp. 1-10, 2012.

[13] Q. Kritzinger, "Antimicrobial activity and fumonisins associated with cowpea (Vigna unguiculata)," Journal of Phytopathology, vol. 14, pp. 1-12, 2005.

[14] E. Ngadze, D. Icishahayo, T. Coutinho, and J. Van der Waals, "Mitteilungen der DGPPN," Die Psychiatrie, vol. 9, no. 3, pp. 186-192, 2012.

[15] D. Mani, C. Kumar, and N. K. Patel, "Integrated microbiochemical approach for phytoremediation of cadmium and lead contaminated soils using Gladiolus grandiflorus L. cut flower," Ecotoxicology and Environmental Safety, vol. 124, pp. 435-446, 2015.

[16] W. Raza, M. U. Ghazanfar, Y. Iftikhar, K. S. Ahmed, N. Haider, and M. H. Rasheed, "Management of early blight of tomato through the useof plant extracts," International Journal of Zoology, vol. 1, no. 5, pp. 1-4, 2016.

[17] M. A. Ghannoum and L. B. Rice, "Antifungal agents: mode of action, mechanisms of resistance, and correlation of these mechanisms with bacterial resistance," Clinical Microbiology Reviews, vol. 12, no. 4, pp. 501-517, 1999.

[18] H. Bandor, A. Hijazi, A. Hachem, Z. Saad, and B. Badran, "Techniques for the extraction of bioactive compounds from labanese Urtica diotica," American Journal Phytomedicine Clinical Therapeutics, vol. 1, pp. 1-10, 2013.

[19] A. R. Nunes, M. G. Alves, G. D. Tomás et al., "Daily consumption of white tea (Camellia sinensis (L.)) improves the cerebral cortex metabolic and oxidative profile in prediabetic Wistar rats," British Journal of Nutrition, vol. 113, no. 5, pp. 832-842, 2015.

[20] M. A. Siddique, "Allelopathic effects of 'Fimbristylis miliacea' on the physiological activities of five Malaysian rice varieties," Australian Journal of Crop Science, vol. 7, pp. 2062-2069, 2013.

[21] J. C. Murimwa, J. T. Rugare, S. Mabasa, and R. Mandumbu, "Allelopathic effects of aqueous extracts of Sorghum (Sorghum bicolor L. Moench) on the early seedling growth of Sesame (Sesamum indicum L.) varieties and selected weeds," International Journal of Agronomy, vol. 2019, pp. 1-12, 2019.

[22] N. B. Singh, "Allelopathic stress produced by bitter gourd (Momordica charantia L.)," Journal of Stress Physiology and Biochemistry, vol. 10, pp. 5-14, 2014.

[23] J. A. Martínez, "Natural fungicides obtained from plants with fungicides," Journal of Plant and Animal Disease, vol. 28, pp. 1-16, 2012.

[24] S. Vanitha, S. Niranjana, and S. Umesha, "Role of phenylalanine ammonia lyase and polyphenol oxidase in host resistance to bacterial wilt of tomato," Journal of Phytopathology, vol. 157, pp. 552-557, 2009.

[25] K. Pourcel, J. M. Routaboul, V. Cheynier, L. Lepiniec, and I. Debeaujon, "Flavonoid oxidation in plants: from biochemical properties to physiological functions," Trends of Plant Science, vol. 12, pp. 29-36, 2007.

[26] C. Mvumi, E. Ngadze, D. Marais, E. S. duToit, and J. Kugara, "Determination and quantification of sinigrin glucosinolates in Alternaria solani susceptible tomato (Solanum lycopersicum) leaves treated with moringa (Moringa oleifera) leaf extract," Archives Phytopathology and Plant Protection, vol. 1, pp. 1-13, 2018.

[27] G. Yan, S. Liping, and Z. Yongliang, "UPLC-Q-Orbitrap-MS2 analysis of Moringa oleifera oleifera leaf extract and its antioxidant, antibacterial and anti-inflammatory activities," National Product Reserch, vol. 34, no. 14, pp. 2090-2094, 2019.
[28] S. Patil, S. Kumbahr, and V. Ambhore, "Evaluation of unsaponified petroleum ether extract of Lantana camara L. leaves for antioxidant activity and Oxidative stress," Journal of Basic and Applied Sciences, vol. 7, pp. 511-515, 2017.

[29] P. Shriniwas and T. Subhash, "Evaluation of terpene-rich extract of Lantana camara L. leaves for antimicrobial activity against mycobacteria using resazurin microtiter assay (REMA)," Journal of Basic and Applied Sciences, vol. 7, pp. 511-515, 2018.

[30] S. Rouhallah and M. Choong, "Biogenic volatile compounds for plant disease diagnosis and health improvement," Journal of Plant Pathology, vol. 6, pp. 559-569, 2018.

[31] E. O’Boyle, "Classical economics and the great Irish famine: a study in limits," Forum for Social Economics, vol. 35, pp. 21-53, 2006. 